\title{
Plasticity of Calcium Signaling Cascades in Human Embryonic Stem Cell-Derived Neural Precursors
}

\author{
Oksana Forostyak, ${ }^{1}$ Nataliya Romanyuk, ${ }^{2}$ Alexei Verkhratsky, ${ }^{3}$ Eva Sykova, ${ }^{2,4}$ and Govindan Dayanithi ${ }^{1,5}$
}

Human embryonic stem cell-derived neural precursors (hESC NPs) are considered to be a promising tool for cellbased therapy in central nervous system injuries and neurodegenerative diseases. The $\mathrm{Ca}^{2+}$ ion is an important intracellular messenger essential for the regulation of various cellular functions. We investigated the role and physiology of $\mathrm{Ca}^{2+}$ signaling to characterize the functional properties of CCTL14 hESC NPs during long-term maintenance in culture (in vitro). We analyzed changes in cytoplasmic $\mathrm{Ca}^{2+}$ concentration $\left(\left[\mathrm{Ca}^{2+}\right]_{\mathrm{i}}\right)$ evoked by high $\mathrm{K}^{+}$, adenosine-5'-triphosphate (ATP), glutamate, $\gamma$-aminobutyric acid (GABA), and caffeine in correlation with the expression of various neuronal markers in different passages (P6 through P10) during the course of hESC differentiation. We found that only differentiated NPs from P7 exhibited significant and specific $\left[\mathrm{Ca}^{2+}\right]_{\mathrm{i}}$ responses to various stimuli. About $31 \%$ of neuronal-like P7 NPs exhibited spontaneous $\left[\mathrm{Ca}^{2+}\right]_{\mathrm{i}}$ oscillations. Pharmacological and immunocytochemical assays revealed that P7 NPs express L- and P/Q-type Ca ${ }^{2+}$ channels, $\mathrm{P} 2 \mathrm{X}_{2}, \mathrm{P} 2 \mathrm{X}_{3}, \mathrm{P} 2 \mathrm{X}_{7}$, and P2Y purinoreceptors, glutamate receptors, and ryanodine (RyR1 and RyR3) receptors. The ATP- and glutamate-induced $\left[\mathrm{Ca}^{2+}\right]_{\mathrm{i}}$ responses were concentration-dependent. Higher glutamate concentrations (over $100 \mu \mathrm{M}$ ) caused cell death. Responses to ATP were observed in the presence or in the absence of extracellular $\mathrm{Ca}^{2+}$. These results emphasize the notion that with time in culture, these cells attain a transient period of operative $\mathrm{Ca}^{2+}$ signaling that is predictive of their ability to act as stem elements.

\section{Introduction}

$\mathrm{H}$ UMAN EMBRYONIC STEM CELLS (hESCS) are pluripotent cells derived from the inner cell mass of a preimplantation embryo [1]. In vitro, these cells are able to maintain a normal euploid kariotype, differentiate into derivatives of all 3 germ layers, and proliferate extensively [2,3]. These properties make them unique candidates for cell transplantation, research into growth factors and early human development, and for drug discovery. Substantial progress has been made recently in the differentiation of hESCs into a neuronal phenotype [3-5], this being a promising strategy for cell-based therapy of central nervous system injuries and neurodegenerative diseases. However, to date, several important questions remain unanswered: (1) when and at what stage of differentiation should cells be transplanted; (2) what are the functional properties (ion channels, receptors, and second messengers) of these cells and how are they regulated; and (3) how compatible are these properties with the physiological or pathological environment at the site of transplantation and treatment? Hitherto, with a few exceptions, the quality of stem cells is generally evaluated by determining the expression of various genes and key proteins during the process of differentiation; these however, although being present in the cell, may be physiologically inactive. Therefore, the aim of this study was, for the first time, to determine and characterize $\mathrm{Ca}^{2+}$ signals activated by physiological stimulation of neural precursors (NPs) derived from hESCs.

$\mathrm{Ca}^{2+}$ is a ubiquitous second messenger involved in the regulation of almost all known cellular processes and, above all, in defining the life and death of every cell [6-10]. Signals mediated by $\mathrm{Ca}^{2+}$ are fundamental for fertilization, cell differentiation, proliferation [11], intercellular signaling, transcription factor activation, and various death programs including necrosis and apoptosis [12]. $\mathrm{Ca}^{2+}$ can enter the cytoplasm from 2 sources: either by an influx via plasmalemmal voltage-operated and receptor-operated $\mathrm{Ca}^{2+}$ channels (VOCC and ROCC respectively) or by release from intracellular stores, such as the endoplasmic reticulum, through endomembrane $\mathrm{Ca}^{2+}$ channels classified as

Departments of ${ }^{1}$ Molecular Neurophysiology, and ${ }^{2}$ Neuroscience, Institute of Experimental Medicine, Academy of Sciences of the Czech Republic, Prague, Czech Republic.

${ }^{3}$ School of Biological Sciences, University of Manchester, Manchester, United Kingdom.

${ }^{4}$ Department of Neuroscience, Second Medical Faculty, Charles University, Prague, Czech Republic.

${ }^{5}$ Institut National de la Santé et de la Recherche Médicale, Unité de recherche U710, Université Montpellier 2, Montpellier; and Ecole Pratique des Hautes Etudes, Paris, France. 
inositol-1,4,5-trisphosphate receptors ( $\left.\mathrm{InsP}_{3} \mathrm{Rs}\right)$ and ryanodine receptors (RyRs). The variety of functions executed by $\mathrm{Ca}^{2+}$ depends on the speed, amplitude, and spatiotemporal pattern of $\mathrm{Ca}^{2+}$ signals and by interactions between $\mathrm{Ca}^{2+}$ and other signaling pathways [9]. For example, changes in $\left[\mathrm{Ca}^{2+}\right]_{i}$ following the activation of purinoceptors ( $\mathrm{P} 2 \mathrm{X}_{3}$, $\mathrm{P}_{2} \mathrm{X}_{4}, \mathrm{P}_{2} \mathrm{Y}_{1}$, and $\mathrm{P}_{2} \mathrm{Y}_{2}$ ) promote cell proliferation in murine ESCs [13]. On the other hand, glial excitability depends on $\mathrm{Ca}^{2+}$ waves that often occur as a result of adenosine-5'-triphosphate (ATP)-mediated signaling through P2Y receptors [14]. The entry of $\mathrm{Ca}^{2+}$ through VOCC and the release of $\mathrm{Ca}^{2+}$ from internal stores modulate neuronal excitability [15]. A transient increase in $\left[\mathrm{Ca}^{2+}\right]$ regulates cellular secretion and cellular motility during neuronal development [16]. Both $\gamma$-aminobutyric acid (GABA) and glutamate have been shown to influence NP cell proliferation during development $[17,18]$. Hence, a detailed characterization of the $\mathrm{Ca}^{2+}$ signaling cascades that are activated by various stimuli is useful in determining the functional state of the cell and may even predict its fate.

In the previous work we have described a novel protocol for the efficient generation of NPs from hESCs [19]. Our results showed that (1) hESC NPs are able to differentiate into a neuronal phenotype and to develop into functionally active neurons; (2) P8 hESC NPs are the appropriate candidate for transplantation compared to undifferentiated hESCs and to P1, P5, and P10; (3) long-term maintenance in vitro decreases tumorogenisity, although simultaneously attenuates proliferative activity and differentiation potential. Our study further revealed that the profile of NPs changes with the length of maintenance in culture.

To date, the role of $\mathrm{Ca}^{2+}$, its homeostasis and signaling potential in ESCs differentiated to a neuronal phenotype have not been studied. To our knowledge there are only a few reports available on mouse ESCs $[20,21]$ and on hESCs differentiated toward neurones [22-25]. Therefore, we undertook the present study to determine whether the functional properties of NPs change during long-term maintenance in culture. We also asked at what stage of differentiation are these cells in ideal physiological condition? We identified and analyzed molecular cascades of $\left[\mathrm{Ca}^{2+}\right]_{\mathrm{i}}$ homeostasis and $\mathrm{Ca}^{2+}$ signaling in correlation with hESC differentiation into a neuronal phenotype.

\section{Materials and Methods}

\section{Drugs and solutions}

Chemicals obtained from Sigma-Aldrich: accutase, laminin, cadmium chloride, nickel chloride, nicardipine hydrochloride, ATP, $\alpha, \beta$-Methyleneadenosine 5 'triphosphate lithium salt $(\alpha, \beta$-MeATP), suramin sodium salt, pyridoxal phosphate-6-azo(benzene-2,4-disulfonic acid) tetrasodium salt hydrate (PPADS), 2'(3')-O-(4-Benzoylbenzoyl)adenosine 5 'triphosphate triethylammonium salt (BzATP), L-Glutamic acid potassium salt monohydrate, N-Methyl-D-aspartic acid (NMDA), kainic acid, GABA, adenosine, $\beta$-mercaptoethanol, bovine serum albumin, and Triton-X 100; from GIBCO: Dulbecco's modified Eagle's medium (DMEM)/F12, Lglutamine, penicillin/streptomycin, fetal bovine serum, collagenase type IV, and B27; from Invitrogen: human recombinant fibroblast growth factor (hrFGF), Fura-2 AM
$1 \mathrm{mM}$ solution in anhydrous dimethyl sulfoxide (DMSO) cell permeant, and 4',6-diamidino-2-phenylindole dihydrochloride (DAPI); from R\&D Systems: human recombinant epidermal growth factor (hrEGF); from Molecular Probes (Eugene, OR): goat anti-mouse IgG conjugated with AlexaFluor 594, goat anti-rabbit IgG conjugated with Alexa-Fluor 488, and Pluronic F-127; from Tocris Bioscience: NF279; from Polysciences, Inc. (Warrington, PA): Aqua Poly/Mount mounting medium; from Alomone Labs Ltd.: caffeine, ryanodine, cyclopiazonic acid (CPA), $\omega$-conotoxin MVIIC (MVIIC), and $\omega$-conotoxin GVIA (GVIA).

Concentrated stock solutions of nicardipine, glutamate, and ryanodine were prepared in DMSO, while the remaining stock solutions of agonists/antagonists were dissolved in $\mathrm{dH}_{2} \mathrm{O}$. For each experiment, caffeine was freshly dissolved in Normal Locke's buffer (NL) at $37^{\circ} \mathrm{C}$ and vortexed until the caffeine crystals dissolved. All concentrated stock solutions were stored at $-20^{\circ} \mathrm{C}$. Test solutions were daily prepared using aliquots from frozen stocks to obtain the working concentrations. All buffers and solutions in this study were made using ion-free $\mathrm{dH}_{2} \mathrm{O}$ from Merck, Germany.

\section{hESC and hESC NP culture}

hESCs line CCTL14 (complete information on the derivation and characterization of CCTL14 line of hESCs is available at www.isscr.org/science/sclines.htm) were cultured on a feeder layer of mitomycin-C-treated mouse embryonic fibroblasts in gelatin-coated tissue culture dishes. The culture medium (CM) was (D-MEM/F-12 without L-glutamine) supplemented with $15 \%$ fetal bovine serum, $1 \%$ nonessential amino acids, $2 \mathrm{mM}$ L-glutamine, penicillin, and streptomycin at $50 \mathrm{U} / \mathrm{mL}, 0.1 \mathrm{mM} \quad \beta$-mercaptoethanol, and $4 \mathrm{ng} / \mathrm{mL}$ hrFGF. Colonies of hESCs were passaged every 4-7 days using either mechanical scraping with a glass pipette to provide low-density cultures of undifferentiated cells or enzymatic dissociation with collagenase type IV to provide high-density cultures of undifferentiated cells [19].

NPs were derived from the CCTL14 line of human ESCs as described previously [19]. Briefly, to induce neural differentiation, clumps of undifferentiated hESCs were plated in agarose-coated tissue culture dishes with $\mathrm{CM}$ without hrFGF for 4 days, then with CM supplemented with Noggin for the next 4 days. At this time, $70 \%-90 \%$ of the colonies formed embryoid bodies (EBs). Aggregates whose diameter exceeded $0.5 \mathrm{~mm}$ were dissected into smaller clumps with $20 \mathrm{G}$ surgical blades, then replaced in serum-free medium or NP medium (NPM) and cultured for 6 days. At this stage, cells in the EBs were defined as passage 1. NPM consisted of DMEM/F12 medium (1:1), B27 supplement (1:50), $2 \mathrm{mM}$ L-glutamine and penicillin, and streptomycin at $50 \mathrm{U} / \mathrm{mL}$, supplemented with $20 \mathrm{ng} / \mathrm{mL}$ hrEGF and $20 \mathrm{ng} / \mathrm{mL}$ hrFGF. For the long-term propagation of hESC NPs, the EBs were dissociated by accutase and the cells were plated onto laminin-coated culture dishes. NPs were cultured in NPM and passaged by accutase each 5-7 days.

\section{Antibodies and immunocytochemistry}

Cells plated onto laminin-coated coverslips were washed in phosphate-buffered saline (0.1 M PBS, pH 7.2) and fixed with $4 \%$ paraformaldehyde in PBS for $15 \mathrm{~min}$. The fixed cells 
were washed twice in PBS prior to immunostaining. Permeabilization and blocking were carried out in a blocking buffer consisting of $0.4 \%$ Triton-X 100 and $10 \%$ bovine serum albumin in $0.1 \mathrm{M}$ PBS for $45 \mathrm{~min}$ at $22^{\circ} \mathrm{C}$. Primary antibodies (See Table 1) were diluted in buffer consisting of $0.1 \%$ TritonX 100 and $2 \%$ bovine serum albumin in PBS overnight at $4^{\circ} \mathrm{C}$. After 2 washes with PBS, appropriate secondary antibodies (Alexa Fluor 488-conjugated goat anti-rabbit IgG [1:200] or Alexa Fluor 594-conjugated goat anti-mouse IgG [1:200]), were applied for $30 \mathrm{~min}$ at $22^{\circ} \mathrm{C}$. To visualize the cell nuclei, the coverslips were incubated with $300 \mathrm{nM}$ DAPI in PBS for $5 \mathrm{~min}$ at $22^{\circ} \mathrm{C}$. Finally, the coverslips with cells were mounted using Aqua Poly/Mount mounting medium and examined using a ZEISS LSM 510 DUO confocal microscope (Carl Zeiss).

\section{Dye loading and measurements of intracellular $\left[\mathrm{Ca}^{2+}\right]_{i}$}

$\left[\mathrm{Ca}^{2+}\right]_{\mathrm{i}}$ measurements on single cells were performed as previously reported [26-31]. Briefly, cultures of hESC NPs, plated on $24 \mathrm{~mm}$ glass-bottom dishes (WillCo-dish, WillCo Wells B.V, Amsterdam, Netherlands) coated with laminin, were incubated with $2.5 \mu \mathrm{M}$ Fura- $2 \mathrm{AM}$ with $0.02 \%$ Pluronic F-127 in $\mathrm{CM}$ at $37^{\circ} \mathrm{C}$ and $5 \% \mathrm{CO}_{2}$ for $40 \mathrm{~min}$. Loaded cells were then washed and the $\mathrm{CM}$ replaced with $\mathrm{NL}$ buffer containing (in $\mathrm{mM}$ ): $\mathrm{NaCl}, 140 ; \mathrm{KCl}, 5 ; \mathrm{MgCl} 2,1.2 ; \mathrm{CaCl}_{2}, 2.2$; glucose, 10; and HEPES-Tris, 10; $\mathrm{pH} 7.25$ and kept at $37^{\circ} \mathrm{C}$ throughout the time course of the experiment. The osmolarity of the buffer was $298-300 \mathrm{mosmol} / \mathrm{1}^{-1}$. Fluorescence mea- surements of $\left[\mathrm{Ca}^{2+}\right]_{i}$ were performed with a fast fluorescence microspectrofluorimetry system based on an inverted microscope (Axiovert, Zeiss) equipped for epifluorescence (PlanNeofluar $100 x / 1.30$ oil immersion objective). To achieve fast switching between different excitation wavelengths, a rotating filter wheel was mounted in the excitation light path. The cells were alternately illuminated $(200 \mathrm{~Hz})$ at $340 \pm 10 \mathrm{~nm}$ and $380 \pm 10 \mathrm{~nm}$. To minimize the background noise of the Fura- 2 signal, successive values were averaged to a final time resolution of $320 \mathrm{~ms}$. A measuring amplifier was synchronized to the filter wheel to measure the fluorescence intensities resulting from different wavelengths. The FFP software controlled the acquisition of the intensity data and provided functions for adjusting the signal values and the display and storage of the measured data. A CCD camera was used to visualize the cells. The $\left[\mathrm{Ca}^{2+}\right]_{i}$ measurement values are expressed as the ratio units (RU) between the fluorescence obtained with 2 excitation wavelengths, $340 \mathrm{~nm}$ (A) and $380 \mathrm{~nm}$ (B). Fura-2 calibration was performed in these cells in vitro following the procedure described by Lambert et al. [32] and Jamen et al. [33], which yielded $R_{\min }=0.08, R_{\max }=2.02$, $\beta=1.757$, and $K_{d}=224$ at $37^{\circ} \mathrm{C}$.

\section{Drug application}

As described previously $[28,34,35]$, the control and test solutions were applied using a temperature controlled multichannel polypropylene capillary perfusion system (Warner Instruments, Inc.). A single outlet capillary tubing $(100 \mu \mathrm{m}$

Table 1. Antibodies Used for Immunocytochemistry

\begin{tabular}{|c|c|c|c|c|}
\hline Antibody & Dilution & Host/Antibody type & Company & Secondary antibody used \\
\hline Anti-NeuN & 1:100 & Mouse monoclonal & Merck Millipore & Alexa Fluor 594 goat anti-mouse IgG \\
\hline Anti- $\beta$-tubulin isotype III & $1: 1000$ & Mouse monoclonal & Sigma-Aldrich & Alexa Fluor 594 goat anti-mouse IgG \\
\hline Anti-MAP-2 & 1:1000 & Mouse monoclonal & $\begin{array}{l}\text { Merck Millipore } \\
\text { Chemicon }\end{array}$ & Alexa Fluor 594 goat anti-mouse IgG \\
\hline Anti-nestin & 1:2000 & Mouse monoclonal & Merck Millipore & Alexa Fluor 594 goat anti-mouse IgG \\
\hline $\begin{array}{l}\text { Anti-myelin/ } \\
\text { oligodendrocyte } \\
\text { specific protein }\end{array}$ & $1: 250$ & Mouse monoclonal & $\begin{array}{l}\text { Merck Millipore } \\
\text { Chemicon }\end{array}$ & Alexa Fluor 594 goat anti-mouse IgG \\
\hline Anti-S100 & $1: 400$ & Rabbit polyclonal & DAKO Denmark & Alexa Fluor 488 goat anti-rabbit IgG \\
\hline Anti-GFAP & $1: 80$ & Rabbit & Sigma-Aldrich & Alexa Fluor 488 goat anti-rabbit IgG \\
\hline Anti-glutamine synthetase & $1: 1000$ & Mouse monoclonal & Merck Millipore & Alexa Fluor 594 goat anti-mouse IgG \\
\hline Anti-glutamate & $1: 1000$ & Mouse monoclonal & Sigma-Aldrich & Alexa Fluor 594 goat anti-mouse IgG \\
\hline Anti-GABA & $1: 500$ & Mouse monoclonal & Sigma-Aldrich & Alexa Fluor 594 goat anti-mouse IgG \\
\hline Anti-Iba1 & 1:1000 & Rabbit polyclonal & Wako Chemicals GmbH & Alexa Fluor 488 goat anti-rabbit IgG \\
\hline Anti-NG2 & $1: 400$ & Rabbit polyclonal & Merck Millipore & Alexa Fluor 488 goat anti-rabbit IgG \\
\hline Anti-L-type $\mathrm{Ca}^{2+} \mathrm{CP} \alpha 1 \mathrm{C}$ & $1: 100$ & Rabbit polyclonal & Santa Cruz Biotechnology & Alexa Fluor 488 goat anti-rabbit IgG \\
\hline Anti-N type $\mathrm{Ca}^{2+} \mathrm{CP} \alpha 1 \mathrm{~B}$ & $1: 100$ & Rabbit polyclonal & Santa Cruz Biotechnology & Alexa Fluor 488 goat anti-rabbit IgG \\
\hline $\begin{array}{l}\text { Anti-P/Q-type } \mathrm{Ca}^{2+} \\
\mathrm{CP} \propto 1 \mathrm{~A}\end{array}$ & $1: 100$ & Rabbit polyclonal & Santa Cruz Biotechnology & Alexa Fluor 488 goat anti-rabbit IgG \\
\hline Anti-P2X2 & $1: 100$ & Rabbit polyclonal & Alomone Labs & Alexa Fluor 488 goat anti-rabbit IgG \\
\hline Anti-P2X3 & $1: 100$ & Rabbit polyclonal & Alomone Labs & Alexa Fluor 488 goat anti-rabbit IgG \\
\hline Anti-P2X4 & $1: 100$ & Rabbit polyclonal & Alomone Labs & Alexa Fluor 488 goat anti-rabbit IgG \\
\hline Anti-P2X6 & $1: 100$ & Rabbit polyclonal & Alomone Labs & Alexa Fluor 488 goat anti-rabbit IgG \\
\hline Anti-P2X7 & $1: 100$ & Rabbit polyclonal & Alomone Labs & Alexa Fluor 488 goat anti-rabbit IgG \\
\hline Anti-RyR 3 & $1: 100$ & Rabbit polyclonal & Alomone Labs & Alexa Fluor 488 goat anti-rabbit IgG \\
\hline Anti-RyR 2 & $1: 200$ & Rabbit polyclonal & Alomone Labs & Alexa Fluor 488 goat anti-rabbit IgG \\
\hline Anti-RyR 1 & $1: 200$ & Rabbit polyclonal & Alomone Labs & Alexa Fluor 488 goat anti-rabbit IgG \\
\hline Anti-NMDA $\varepsilon 4$ & $1: 100$ & Rabbit polyclonal & $\begin{array}{l}\text { Santa Cruz } \\
\text { Biotechnology }\end{array}$ & Alexa Fluor 594 goat anti-rabbit IgG \\
\hline
\end{tabular}

GFAP, glial fibrillary acidic protein; GABA, $\gamma$-aminobutyric acid; RyR, ryanodine receptor; NMDA, N-Methyl-D-aspartic acid. 
inner diameter) with a flow rate of $250 \mu \mathrm{L} / \mathrm{min}$ was positioned close to the tested cell $(0.5 \mathrm{~mm})$. The selected cell was subjected to a constant flow of control buffer or test solutions. Each capillary was fed by a reservoir $45 \mathrm{~cm}$ above the bath and connected to a temperature control device (Harvard). The temperature of all solutions was maintained at $37^{\circ} \mathrm{C}$. In this approach, switching the flow from one capillary to the next resulted in complete solution exchange within 1-3s. After each application of the tested drug, the cells were washed with control buffer. This method allowed for the fast and reliable exchange of the solution surrounding the selected cell under observation without exposing the neighboring cells.

\section{Data analysis and statistical methods}

Origin 8.5.1 was employed for plotting and statistical procedures. The results are expressed as mean \pm SEM. The number of the sample size (n) given is the number of cells tested according to the same protocol (control, test drug, and recovery) for each group. The figures (traces) show on-line single cell measurements of the $\left[\mathrm{Ca}^{2+}\right]_{i}$ levels before and after the application of test substances, while bar diagrams and numerical data are given as mean \pm S.E.M. and present the peak amplitude of the $\left[\mathrm{Ca}^{2+}\right]_{i}$ increase as a ratio between the fluorescence values of $340 / 380 \mathrm{~nm}$ excitation wavelengths. The results were analyzed using one-way ANOVA. Differences were considered statistically significant if $P \leq 0.05$.

\section{Results}

$\left[\mathrm{Ca}^{2+}\right]_{i}$ responses in undifferentiated hESC

Undifferentiated hESCs $(n=34)$ from 2 independent cultures were subjected to the application of $\mathrm{K}^{+}(50 \mathrm{mM})$, ATP $(100 \mu \mathrm{M})$, glutamate $(50 \mu \mathrm{M})$, GABA $(10 \mu \mathrm{M})$, and CPA $(10 \mu \mathrm{M})$. These cells were only partially responsive to ATP. To identify the specific involvement of the type(s) of active purinergic receptors in undifferentiated hESC, we tested the effect of adenosine diphosphate (ADP; $100 \mu \mathrm{M}$ ) and adenosine $(2 \mu \mathrm{M})$. ADP had no effect, whereas adenosine caused rise in $\left[\mathrm{Ca}^{2+}\right]_{\mathrm{i}}$ in only $18 \%(n=11)$. P2 receptor antagonist suramin $(300 \mu \mathrm{M})$ inhibited ATP-induced $\left[\mathrm{Ca}^{2+}\right]_{\mathrm{i}}$ by $33.3 \% \pm 23 \%(n=4)$, PPADS $(10 \mu \mathrm{M})$ had no effect $(n=3)$.

\section{$\left[\mathrm{Ca}^{2+}\right]_{i}$ responses in hESC NPs change during long term propagation in culture}

The functional properties of hESC NPs were studied during long-term propagation in vitro starting from P6 NPs to P10 NPs. All data within each passage were collected and analyzed from a minimum of 3 independent experiments. Cells were chosen randomly and subjected to the same experimental protocol. The cells from each passage were subjected to various stimuli such as $\mathrm{K}^{+}(50 \mathrm{mM})$, ATP $(100 \mu \mathrm{M})$, glutamate $(50 \mu \mathrm{M})$, GABA $(10 \mu \mathrm{M})$, and caffeine $(20 \mathrm{mM}$; Table 2). The results indicate that P6 NPs were sensitive to the application of glutamate and $\mathrm{K}^{+}(27 \% \pm 1.3 \%$ and $11 \% \pm 1 \%$, respectively). Only a few cells were sensitive to other stimuli such as GABA or ATP $(7 \% \pm 1 \%$ each) and to caffeine $(4 \% \pm 2 \%)$. The percentages of P7 cells responding to $\mathrm{K}^{+}$, ATP, glutamate, GABA, and caffeine were $50 \% \pm 3.9 \%$, $46 \% \pm 2.2 \%, 57 \% \pm 0.3 \%, 5 \% \pm 2.3 \%$, and $18 \% \pm 2.1 \%$, respectively. Similarly, the percentages of P8 NPs responding to $\mathrm{K}^{+}$, ATP, glutamate, GABA, and caffeine were $32 \% \pm 4 \%$, $24 \% \pm 3.5 \%, 9 \% \pm 1.3 \%, 16 \% \pm 1.1 \%$, and $16 \% \pm 1 \%$, respectively. The cells from P9 were responsive to ATP $(9 \% \pm 1.9 \%)$ and nonresponsive to GABA. Less than $5 \%$ of cells were sensitive to other stimuli. P10 NPs were not sensitive to glutamate or GABA, while $5 \% \pm 2.3 \%$ of cells were sensitive to ATP and $2.3 \%$ ( 1 out of 44 cells tested) to $\mathrm{K}^{+}$or caffeine. Immunocytochemical staining for $\mathrm{Ca}^{2+}$ channels and RyRs revealed the expression of L-type and P/Q-type VOCC, ryanodine receptors RyR1 and RyR3, and the weak expression of RyR2 in all passages (Table 3). Since the number of cells responding to physiological stimuli was significantly higher in passage P7 NPs $(59 \% \pm 2.5 \%)$ than in other passages (P6 NPs: 41\% $\pm 1.6 \%$; P8 NPs: $49 \% \pm 1.1 \%$; P9 NPs: $15 \% \pm 1.7 \%$; and P10 NPs: $7 \% \pm 0.2 \%$ ), these cells were chosen for further experimentation in this study.

\section{Characterization of $\left[\mathrm{Ca}^{2+}\right]_{i}$ transients mediated by $\mathrm{Ca}^{2+}$ channels in P7 hESC NPs}

We monitored $\mathrm{Ca}^{2+}$ entry through VOCC as $\left[\mathrm{Ca}^{2+}\right]_{\mathrm{i}}$ transients evoked by depolarization with $50 \mathrm{mM} \mathrm{K}^{+}$. The application of high $\mathrm{K}^{+}$solution evoked a rapid increase in $\left[\mathrm{Ca}^{2+}\right]_{\mathrm{i}}$ in $50 \%(n=145)$ of the tested cells. Preincubation with $\mathrm{Cd}^{2+}(100 \mu \mathrm{M})$, a nonspecific blocker of high-voltage activated (HVA) $\mathrm{Ca}^{2+}$ channels (L- N- P- Q- and R-types), together with $\mathrm{Ni}^{2+}(50 \mu \mathrm{M})$, a more specific blocker of lowvoltage activated $\mathrm{Ca}^{2+}$ channels (T-type), for $5 \mathrm{~min}$ significantly reduced the $\left[\mathrm{Ca}^{2+}\right]_{\mathrm{i}}$ responses induced by $\mathrm{K}^{+}$in all cells tested by $85.3 \% \pm 7.5 \%(n=7)$ indicating the involvement of voltage-activated $\mathrm{Ca}^{2+}$ channels in depolarizationinduced $\mathrm{Ca}^{2+}$ entry (Fig. 1A, B). To further characterize the involvement of specific subtypes of $\mathrm{HVA} \mathrm{Ca}^{2+}$ channels, we used specific $\mathrm{Ca}^{2+}$ channel blockers such as nicardipine (for

Table 2. The Number of Cells Responding to Various Physiological Stimuli in Different Passages of Human Embryonic Stem Cell-Derived Neural Precursors (P6-P10 NPs)

\begin{tabular}{|c|c|c|c|c|c|}
\hline Number of cells tested & $\begin{array}{c}P 6 \text { NPS } \\
\mathrm{n}=44\end{array}$ & $\begin{array}{c}P 7 \text { NPS } \\
\mathrm{n}=44\end{array}$ & $\begin{array}{c}P 8 \text { NPS } \\
\mathrm{n}=45\end{array}$ & $\begin{array}{c}P 9 \text { NPS } \\
\mathrm{n}=45\end{array}$ & $\begin{array}{c}P 10 N P S \\
\mathrm{n}=44\end{array}$ \\
\hline Cells sensitive to 1 or more of applied stimuli & $41 \% \pm 1.6 \%$ & $59 \% \pm 2.5 \%$ & $49 \% \pm 1.1 \%$ & $15 \% \pm 1.7 \%$ & $7 \% \pm 0.2 \%$ \\
\hline $\mathrm{K}^{+} 50 \mathrm{mM}$ & $11 \% \pm 1 \%$ & $50 \% \pm 3.9 \%$ & $32 \% \pm 4 \%$ & $4 \% \pm 2.2 \%$ & $2.3 \%$ \\
\hline ATP $100 \mu \mathrm{M}$ & $7 \% \pm 1 \%$ & $46 \% \pm 2.2 \%$ & $24 \% \pm 3.5 \%$ & $9 \% \pm 1.9 \%$ & $5 \% \pm 2.3 \%$ \\
\hline Glutamate $50 \mu \mathrm{M}$ & $27 \% \pm 1.3 \%$ & $57 \% \pm 0.3 \%$ & $9 \% \pm 1.3 \%$ & $4 \% \pm 2.2 \%$ & 0 \\
\hline GABA $10 \mu \mathrm{M}$ & $7 \% \pm 1 \%$ & $5 \% \pm 2.3 \%$ & $16 \% \pm 1.1 \%$ & 0 & 0 \\
\hline Caffeine $20 \mathrm{mM}$ & $4 \% \pm 2 \%$ & $18 \% \pm 2.1 \%$ & $16 \% \pm 1.1 \%$ & $4 \% \pm 2.1 \%$ & $2.3 \%$ \\
\hline
\end{tabular}

ATP, adenosine-5'-triphosphate. 
Table 3. Expression of Various Neural Markers AND $\mathrm{CA}^{2+}$ Sensitive Channels in P6-P10 hESC NPs

\begin{tabular}{llllll}
\hline & P6 & P7 & P8 & P9 & P10 \\
& NPS & NPS & NPS & NPS & NPS \\
\hline Neural markers & & & & & \\
Nestin & ++ & ++ & ++ & ++ & ++ \\
NeuN & ++ & ++ & ++ & + & + \\
BIII tubulin & +++ & +++ & +++ & ++ & ++ \\
MAP2 & - & - & - & - & - \\
Glutamate & + & +++ & - & - & - \\
GABA & + & - & + & - & - \\
GFAP & ++ & +++ & ++ & + & - \\
S100 & + & ++ & ++ & ++ & ++ \\
OLIG & - & ++ & - & - & - \\
GS & - & ++ & - & - & - \\
NG2 & - & - & - & - & + \\
Ca ${ }^{2+}$-sensitive channels & ++ & +++ & ++ & ++ & ++ \\
L-type VOCC & ++ & & & - & - \\
N-type VOCC & - & - & - & + & + \\
P/Q-type VOCC & ++ & +++ & ++ & ++ \\
RyR 1 & +++ & +++ & +++ & +++ & ++ \\
RyR 2 & + & + & + & + & + \\
RyR 3 & ++ & +++ & ++ & ++ & ++ \\
\hline
\end{tabular}

" -"-negative immunostaining.

" +"-faint positive immunostaining/few cells express the marker.

" ++ " -positive immunostaining/many cells express the marker.

" +++ "-very positive/majority of cells express the marker.

VOCC, voltage-operated $\mathrm{Ca}^{2+}$ channels.

L-type), MVIIC (for P/Q type), and GVIA (for N-type). Application of $10 \mu \mathrm{M}$ nicardipine reduced $\left[\mathrm{Ca}^{2+}\right]_{\mathrm{i}}$ responses in $67 \%$ of tested P7 NPs $(n=12)$. In 2 out of 8 cells nicardipine totally abolished the $\left[\mathrm{Ca}^{2+}\right]_{\mathrm{i}}$ responses (Fig. 1C, D). In the other 6 cells, it significantly reduced the amplitude of the responses by $54 \% \pm 19.5 \%(P=0.03 ; n=6)$, suggesting the contribution of L-type $\mathrm{Ca}^{2+}$ channels in P7 NPs. The application of $300 \mathrm{nM}$ MVIIC (Fig. 1E, F), which is known to block the P/Q-type of VOCC [36], reduced the $\left[\mathrm{Ca}^{2+}\right]_{i}$ responses by $92 \% \pm 32 \%(P=0.004 ; n=5)$ in all cells. The application of MVIIC at a higher concentration $(1 \mu \mathrm{M})$, which was reported to also block $\mathrm{N}$-type $\mathrm{Ca}^{2+}$ channels, completely inhibited the $\mathrm{K}^{+}$-induced responses in the tested cells $(n=3)$. Further, we used another specific N-type VOCC blocker, GVIA, at 2 different concentrations (500 $\mathrm{nM}$ and $800 \mathrm{nM}$ ), which only partially and reversibly reduced the $\mathrm{K}^{+}$-induced responses by $20 \% \pm 14.6 \%(P=0.47 ; n=11)$ and $48 \% \pm 31.8 \% \quad(P=0.27$; $n=9)$, respectively. To confirm the above $\left[\mathrm{Ca}^{2+}\right]_{i}$ measurement results, we performed a series of immunocytochemical analyses. No positive immunostaining for the $\alpha 1 \mathrm{~B}$ subunit of the N-type of VOCC was observed, but positive immunostaining for the $\alpha 1 \mathrm{C}$ subunit of the L-type of VOCC (Fig. $1 \mathrm{G}$ ) and the $\alpha 1 \mathrm{~A}$ subunit of the P/Q-type of VOCC (Fig. $1 \mathrm{H})$ was observed, suggesting the presence of $\mathrm{L}-$ and $\mathrm{P} / \mathrm{Q}-$ type $\mathrm{Ca}^{2+}$ channels in P7 NPs.

\section{$\left[\mathrm{Ca}^{2+}\right]_{i}$ signaling through purinergic receptors in $P 7$ hESC NPS}

The application of ATP $(100 \mu \mathrm{M})$ induced a rapid $\left[\mathrm{Ca}^{2+}\right]_{\mathrm{i}}$ increase in 33 out of $71(47 \%)$ NPs tested with the mean amplitude of $0.8 \pm 0.12$ (RU) (Fig. 2A). The rise in $\left[\mathrm{Ca}^{2+}\right]_{i}$ in response to ATP was significantly inhibited (by $65 \% \pm 25 \%$ ) by the broad-spectrum P2 receptor antagonist suramin $(300 \mu \mathrm{M})$ $(P=0.01 ; n=8)$ (Fig. 2B, C). Another P2 receptor antagonist, PPADS, had a similar effect at a concentration of $10 \mu \mathrm{M}$, decreasing the $\left[\mathrm{Ca}^{2+}\right]_{i}$ response to ATP by $73 \% \pm 20 \%(P=0.02$; $n=8)$, (Fig. 2D, E). These results suggest that functional P2 purinoceptors are present in P7 NPs.

To further identify which P2 receptors (ionotropic P2X or metabotropic P2Y) operate in hESC NPs, we studied the effect of the P2X agonist $\alpha, \beta$-meATP. In $64 \%$ of the cells, the application of $\alpha, \beta$-meATP $(100 \mu \mathrm{M})$ transiently increased $\left[\mathrm{Ca}^{2+}\right]_{\mathrm{i}}$, by a mean amplitude of $0.86 \pm 0.14, n=16$ (Fig. 2A). The application of $20 \mu \mathrm{M}$ BzATP, another P2X receptor agonist, evoked a $\left[\mathrm{Ca}^{2+}\right]_{\mathrm{i}}$ increase in $18 \%$ of the tested cells with the mean amplitude of $0.28 \pm 0.07,(n=22$; Fig. $2 \mathrm{~A})$. The $\mathrm{P} 2 \mathrm{X}$ receptors antagonist, NF279, was ineffective at concentrations from $20 \mathrm{nM}$ to $1 \mu \mathrm{M}$ at which it is specific agonist for $\mathrm{P}_{2} \mathrm{X}_{1}$ receptors (Fig. $2 \mathrm{~F}$ ), whereas at a higher concentration $(100 \mu \mathrm{M})$, it inhibited the ATP-induced $\left[\mathrm{Ca}^{2+}\right]_{\mathrm{i}}$ increase by $69 \% \pm 20.6 \%, P=0.04 ; n=3$ (Fig. 2G). Immunocytochemical staining with antibodies directed against $\mathrm{P} 2 \mathrm{X}_{2}, \mathrm{P} 2 \mathrm{X}_{3}, \mathrm{P} 2 \mathrm{X}_{4}$, $\mathrm{P} 2 \mathrm{X}_{6}$, and $\mathrm{P} 2 \mathrm{X}_{7}$ receptors revealed expression of $\mathrm{P} 2 \mathrm{X}_{2}$ (Fig. $2 \mathrm{H}), \mathrm{P}_{2} \mathrm{X}_{3}$ (Fig. 2I) and P2X $\mathrm{X}_{7} \mathrm{R}$ (Fig. 2J). Finally, to investigate P2Y-mediated $\mathrm{Ca}^{2+}$ signaling, the effects of ATP were examined in $\mathrm{Ca}^{2+}$-free medium. In the absence of extracellular $\mathrm{Ca}^{2+}$, the application of ATP induced an increase in $\left[\mathrm{Ca}^{2+}\right]_{i}$ in $86 \%$ of the tested cells with a mean amplitude of $0.34 \pm 0.15, n=7$ (Fig. 2A). The application of $100 \mu \mathrm{M}$ ADP, a $\mathrm{P}^{2} \mathrm{Y}_{1}$ and $\mathrm{P}_{2} \mathrm{Y}_{12}$ agonist, elevated $\left[\mathrm{Ca}^{2+}\right]_{\mathrm{i}}$ by $0.38 \pm 0.08(n=5)$ in $56 \%$ of the tested cells (Fig. $2 \mathrm{~A}$ ). These data suggest the involvement of both the P2X $\left(\mathrm{P} 2 \mathrm{X}_{2}, \mathrm{P} 2 \mathrm{X}_{3}\right.$, and $\left.\mathrm{P} 2 \mathrm{X}_{7}\right)$ and $\mathrm{P} 2 \mathrm{Y}$ purinoceptors in $\mathrm{Ca}^{2+}$ signaling in P7 NPs.

\section{$\mathrm{Ca}^{2+}$ release from intracellular $\mathrm{Ca}^{2+}$ stores and spontaneous $\left[\mathrm{Ca}^{2+}\right]_{i}$ transients in P7 hESC NPS}

To check for functional intracellular $\mathrm{Ca}^{2+}$ stores in P7 NPs, we used caffeine $(20 \mathrm{mM})$, which in millimolar concentrations acts as an inhibitor of intracellular receptors for $\mathrm{IP}_{3}$ while being a potent activator of RyR. We also applied ryanodine at $1 \mu \mathrm{M}$, the concentration that opens the RyR. A brief application $(10 \mathrm{~s})$ of either caffeine or ryanodine induced a $\left[\mathrm{Ca}^{2+}\right]_{\mathrm{i}}$ rise in $18 \%(n=44)$ and $22 \%(n=9)$ of P7 hESC NPs, respectively. Immunostainings for RyR1 (Fig. 3A) and RyR3 (Fig. 3B) were positive in all tested cells. The application of $10 \mu \mathrm{M} \mathrm{CPA}$, a potent, selective, and reversible inhibitor of the sarco-endoplasmic reticulum $\mathrm{Ca}^{2+}-\mathrm{ATP}_{\text {ase }}$ pump, caused an intracellular $\left[\mathrm{Ca}^{2+}\right]_{\mathrm{i}}$ increase in 12 out of 13 tested cells (92\%) with a mean amplitude of $0.38 \pm 0.05$.

Spontaneous $\left[\mathrm{Ca}^{2+}\right]_{\mathrm{i}}$ transients were observed in 51 out 164 of tested cells $(31 \%)$ in the absence of any stimuli (Fig. $3 C)$. The amplitude of the spontaneous $\left[\mathrm{Ca}^{2+}\right]_{\mathrm{i}}$ transients was $0.74 \pm 0.05(n=91)$, and they appeared with a mean frequency of 1 per $3.2 \mathrm{~min}$. These transients were partially inhibited by the application of VOCC blockers $\left(100 \mu \mathrm{M} \mathrm{Cd}^{2+}\right.$, $50 \mu \mathrm{M} \mathrm{Ni}^{2+}$, and $10 \mu \mathrm{M}$ nicardipine) or completely by the removal of extracellular $\mathrm{Ca}^{2+}$ (Fig. 3D).

\section{$\left[\mathrm{Ca}^{2+}\right]_{i}$ responses to glutamate in P7 hESC NPs}

We tested the $\left[\mathrm{Ca}^{2+}\right]_{i}$ responses of P7 NPs to various concentrations of glutamate $(1 \mu \mathrm{M}-1 \mathrm{mM} ; n=118)$. Out of 118 , the glutamate caused an elevation of $\left[\mathrm{Ca}^{2+}\right]_{\mathrm{i}}$ in 80 cells 

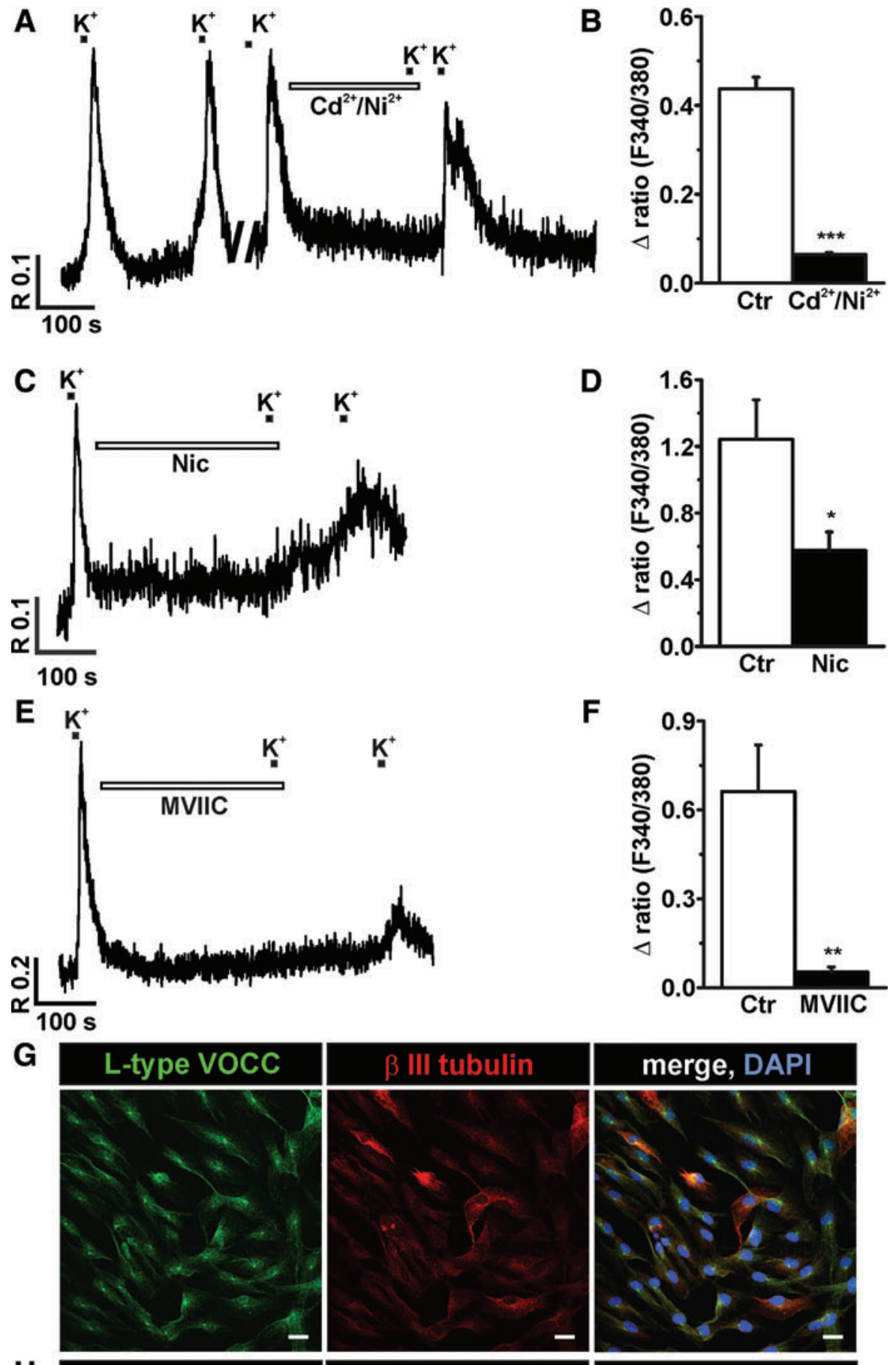

H
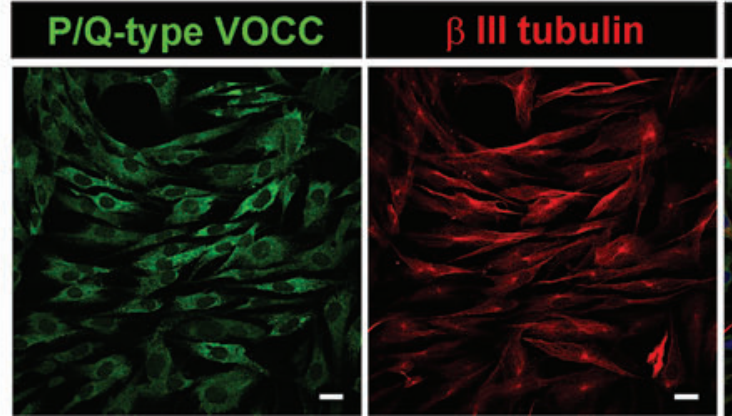

D

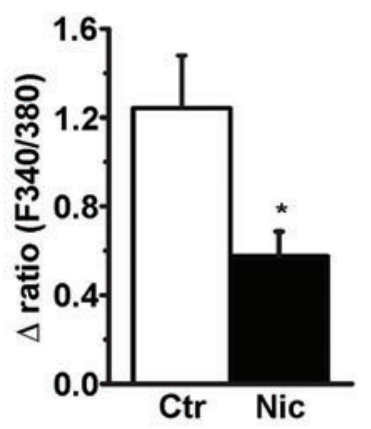

$\mathbf{F}$

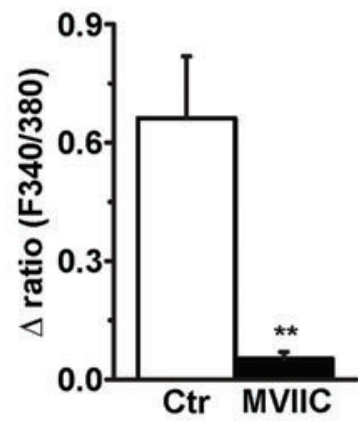

merge, DAPI

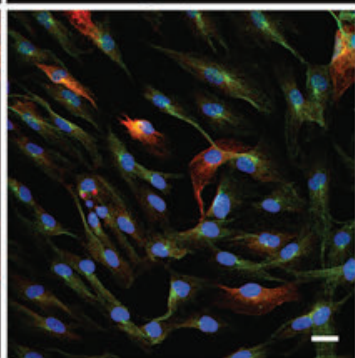

merge, DAPI

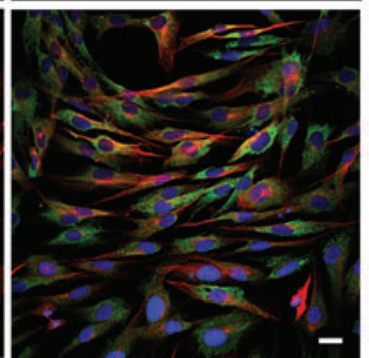

FIG. 1. Voltage-operated $\mathrm{Ca}^{2+}$ channels in P7 human embryonic stem cell-derived neural precursors (hESC NPs). Example of traces (A, C, E) from individual cells for each experimental design show the block of $\mathrm{K}^{+}$responses by specific $\mathrm{Ca}^{2+}$ channel antagonists. The cells were first exposed to control $\mathrm{K}^{+}$depolarization and the $\left[\mathrm{Ca}^{2+}\right]_{i}$ responses were monitored. Note that the amplitude of the control responses to high $\mathrm{K}^{+}$is identical without any run down. Subsequently, the same cell was preincubated for $5 \mathrm{~min}$ with $\mathrm{Ca}^{2+}$ channel blockers $\left[\mathrm{Cd}^{2+} /\right.$ $\mathrm{Ni}^{2+}$; Nic: nicardipine and $\omega$-conotoxin MVIIC (MVIIC)] as indicated on the trace and then again challenged with high $\mathrm{K}^{+}$. (B) Preincubation of cells with $100 \mu \mathrm{M}$ $\mathrm{Cd}^{2+}$ together with $50 \mu \mathrm{M} \mathrm{Ni}{ }^{2+}$ significantly reduced $\left[\mathrm{Ca}^{2+}\right]_{\mathrm{i}}$ responses in all tested cells $(n=7)$. The trace (C) and bar diagram (D) show the reduction of the high $\mathrm{K}^{+}$induced $\left[\mathrm{Ca}^{2+}\right]_{i}$ responses by the $\mathrm{L}$ type $\mathrm{Ca}^{2+}$ channel blocker $10 \mu \mathrm{M}$ nicardipine $(n=6)$. The trace $(\mathrm{E})$ shows the $\mathrm{K}^{+}$-induced $\left[\mathrm{Ca}^{2+}\right]_{i}$ responses in the presence of and after preincubation with the P/Q-type $\mathrm{Ca}^{2+}$ channel blocker, MVIIC $(300 \mathrm{nM})$. (F) Bar diagram shows the MVIIC inhibition of the high- $\mathrm{K}^{+}$responses $(n=5) . \mathbf{G}, \mathbf{H}$ are confocal images of P7 hESC NPs, co-stained for $\beta$ III tubulin $(\mathbf{G}, \mathbf{H})$ (middle panel) and for L-type $\mathrm{Ca}^{2+}$ $\mathrm{CP} \alpha 1 \mathrm{C}(\mathrm{H}-280)(\mathrm{G}),($ left panel) or $\mathrm{P} / \mathrm{Q}$-type $\mathrm{Ca}^{2+} \mathrm{CP} \alpha 1 \mathrm{~A}(\mathrm{H}-90)(\mathrm{H})$, (left panel). Merged images are presented in the right panels $(G, \mathbf{H})$. Scale bars $=20 \mu \mathrm{m}$. ${ }^{*} P=0.05 ;{ }^{*} P=$ 0.005 ; ${ }^{* * *} P=0.0005$. Color images available online at www.liebertpub .com/scd 
FIG. 2. Purinergic responses in P7 hESC NPs. P7 NPs express functional P2X and P2Y purinergic receptors. (A) Bar diagram showing the mean amplitude of the $\left[\mathrm{Ca}^{2+}\right]_{i}$ increase in response to various purinergic receptor agonists in P7 hESC NPs. The cells were exposed to $100 \mu \mathrm{M}$ adenosine-5'-triphosphate (ATP), $100 \mu \mathrm{M}$ $\alpha, \beta$-Methyleneadenosine 5 'triphosphate lithium salt $\left(\alpha, \beta\right.$-meATP), $20 \mu \mathrm{M} 2^{\prime}\left(3^{\prime}\right)$-O(4-Benzoylbenzoyl)adenosine 5 'triphosphate triethylammonium salt (BzATP), and $100 \mu \mathrm{M}$ adenosine diphosphate (ADP). The application of ATP also resulted in a rise in $\left[\mathrm{Ca}^{2+}\right]_{\mathrm{i}}$ in the absence of external $\mathrm{Ca}^{2+}$. (B, D) Representative traces show the ATP-induced $\left[\mathrm{Ca}^{2+}\right]_{\mathrm{i}}$ responses obtained in the presence of and after the washout of the purinergic receptor antagonists suramin and pyridoxal phosphate-6-azo(benzene-2,4-disulfonic acid) tetrasodium salt hydrate (PPADS). Incubation with $300 \mu \mathrm{M}$ suramin or $10 \mu \mathrm{M}$ PPADS after control ATP application significantly inhibited the ATP responses. (C, E) Bar diagrams showing the amplitude of the $\left[\mathrm{Ca}^{2+}\right]_{i}$ response to ATP before (control) and after incubation with the antagonists (C) $300 \mu \mathrm{M}$ suramin $\left({ }^{*} P=0.01, n=8\right)$ and (E) $10 \mu \mathrm{M}$ PPADS $\left({ }^{*} P=0.02, n=8\right)$. (F, G) Bar diagrams showing the effect of NF279 in P7 NPs. At $1 \mu \mathrm{M}$ concentration NF279 had no effect (F), while at $100 \mu \mathrm{M}$ concentration (G) it significantly inhibited ATP-induced $\left[\mathrm{Ca}^{2+}\right]_{\mathrm{i}}$ responses $\left({ }^{*} \mathrm{P}=0.04\right.$; $n=3)$. Confocal images $(\mathbf{H}, \mathbf{I}, \mathbf{J})$ showing the staining for $\mathrm{P}_{2} \mathrm{X}_{2}(\mathrm{H}), \mathrm{P}_{2} \mathrm{X}_{3}(\mathrm{I})$, and $\mathrm{P}^{2} \mathrm{X}_{7}(\mathrm{~J})$ receptors. Cell nuclei are visualized with 4',6-diamidino-2-phenylindole dihydrochloride (DAPI) staining. Scale bars $=20 \mu \mathrm{m}$. Color images available online at www.liebertpub.com/scd
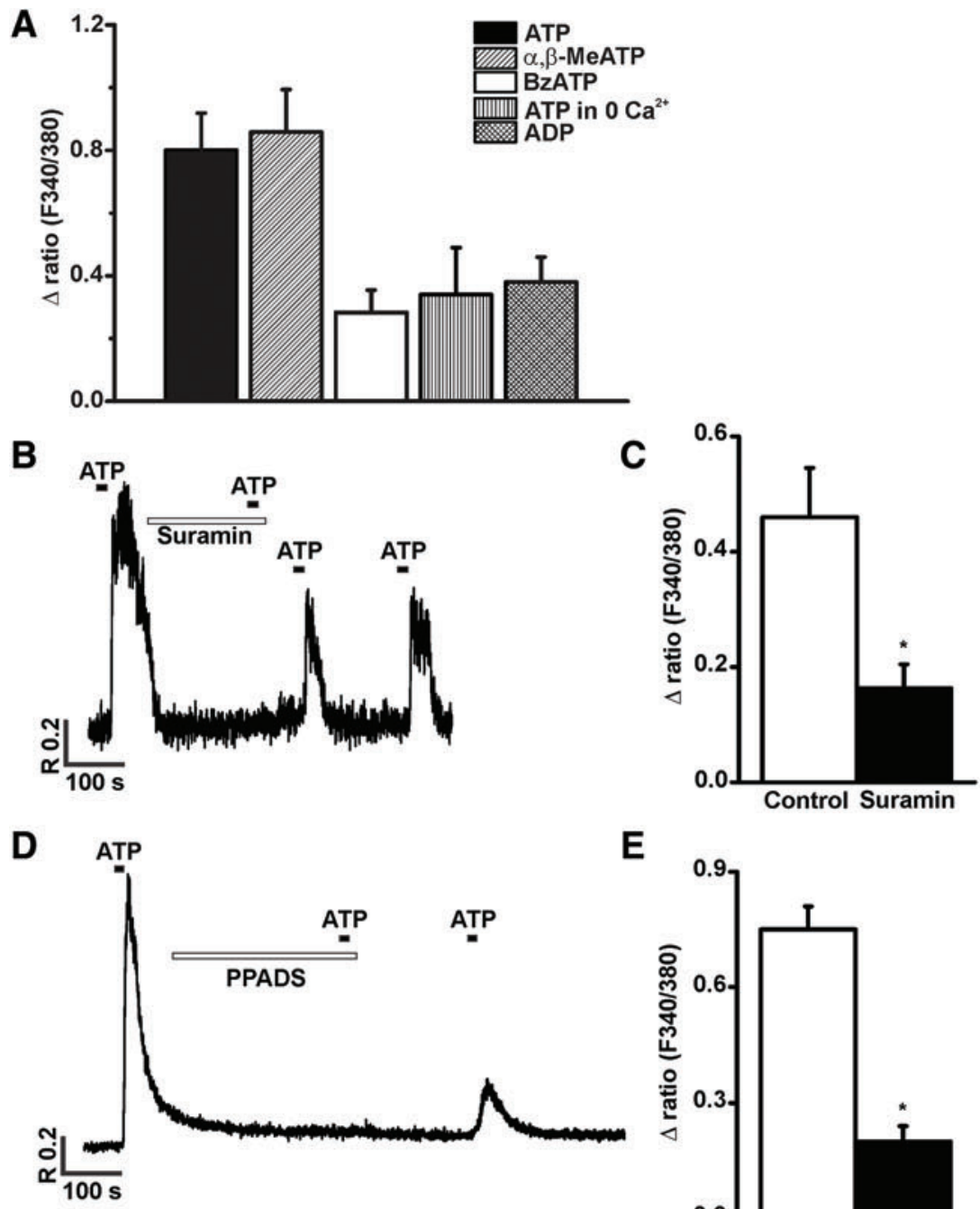

E

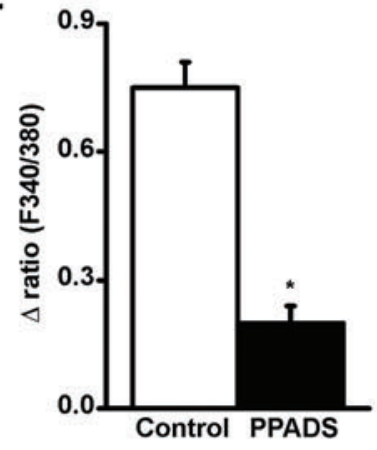

F

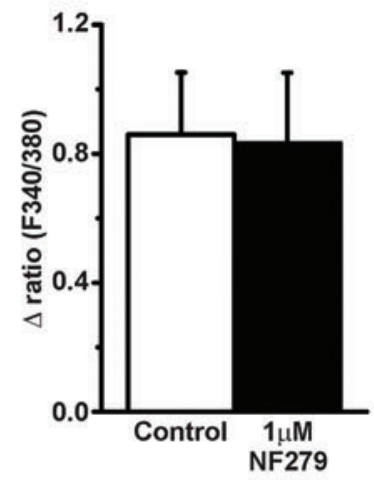

G
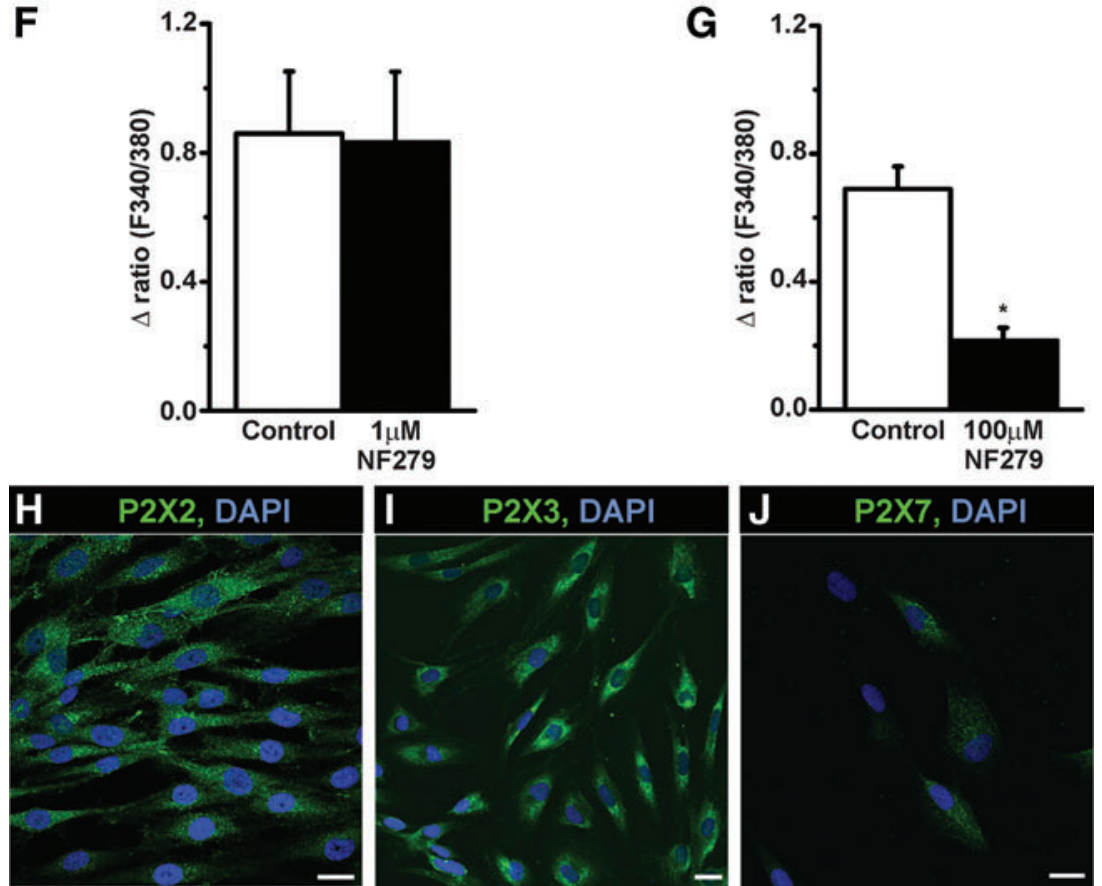

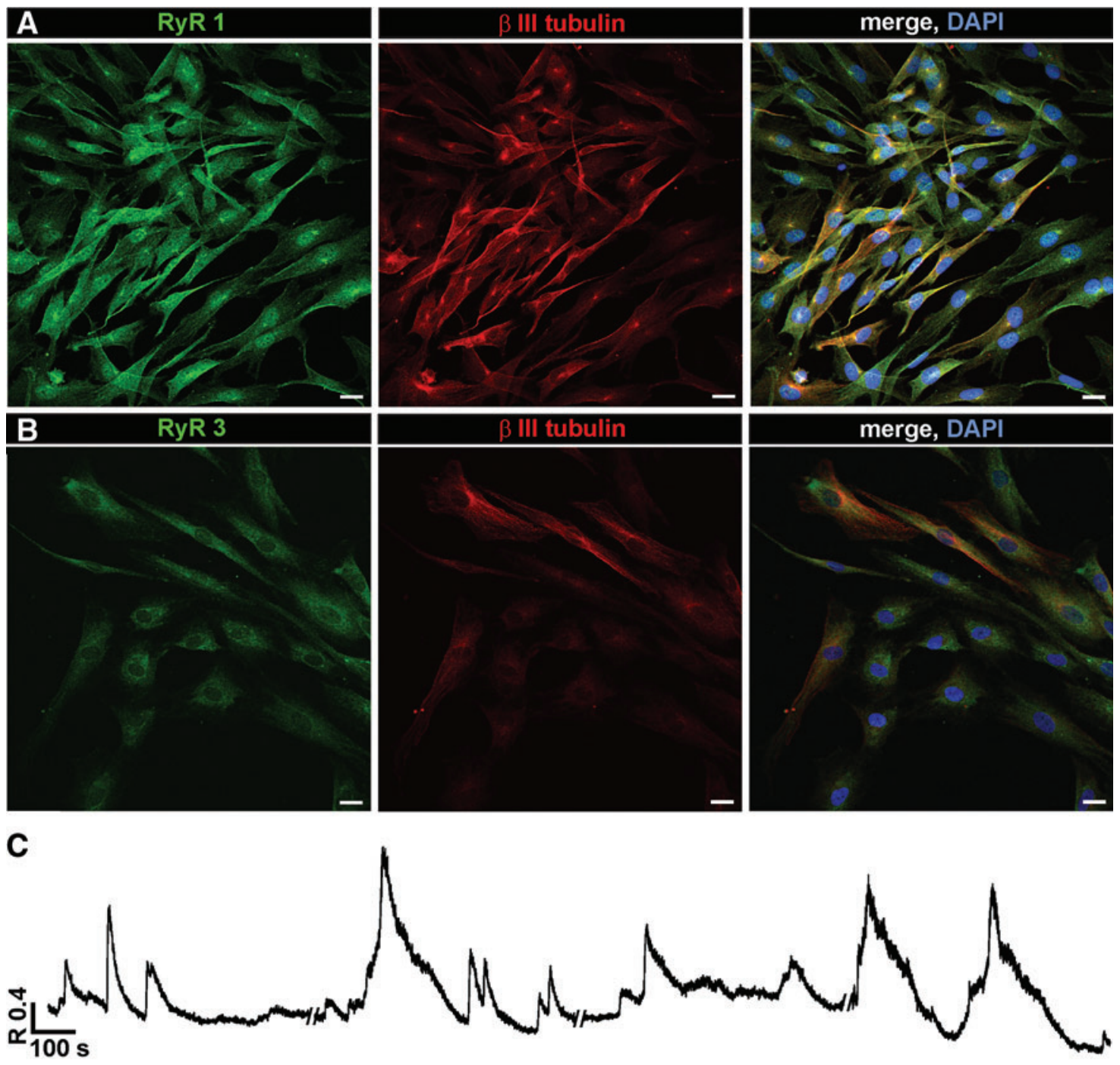

D
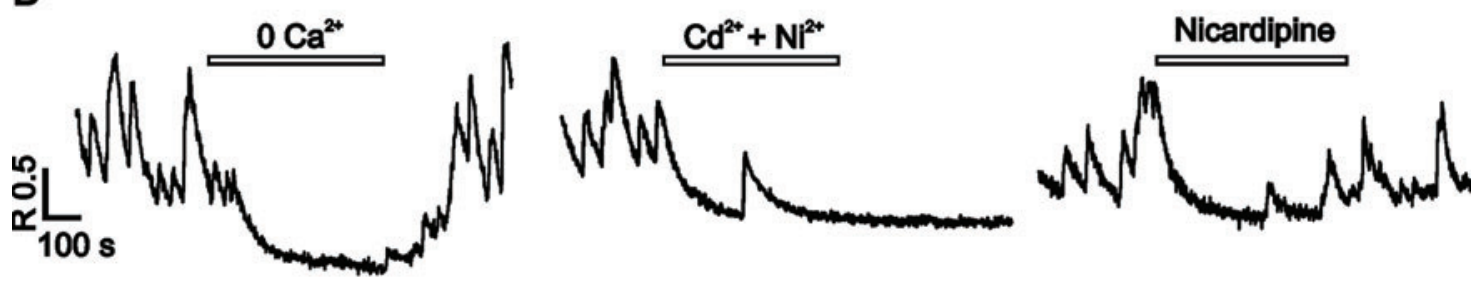

FIG. 3. $\mathrm{Ca}^{2+}$ release from intracellular $\mathrm{Ca}^{2+}$ stores and spontaneous $\left[\mathrm{Ca}^{2+}\right]_{\mathrm{i}}$ transients in P7 hESC NPs. (A, B) Confocal images of P7 hESC NPs. (A) Ryanodine receptor (RyR) 1 and (B) RyR 3 receptors are present in all cells and are co-localized with immunostaining for $\beta$ III tubulin. Scale bars $=20 \mu \mathrm{m}$. (C) A representative trace showing spontaneous $\left[\mathrm{Ca}^{2+}\right]_{\mathrm{i}}$ oscillations observed in the same cell. These types of oscillations were observed in about 31\% of tested P7 hESCs. (D) Traces showing the inhibition of spontaneous $\left[\mathrm{Ca}^{2+}\right]_{\mathrm{i}}$ activity after removal of extracellular $\mathrm{Ca}^{2+}$, application of voltage-operated $\mathrm{Ca}^{2+}$ channels (VOCC) blockers $\mathrm{Cd}^{2+}(100 \mu \mathrm{M})$ and $\mathrm{Ni}^{2+}(50 \mu \mathrm{M})$ and L-type VOCC blocker nicardipine $(10 \mu \mathrm{M})$. Color images available online at www.liebertpub.com/scd

(68\%). Glutamate at $1 \mathrm{mM}$ caused cell death, which was determined by the loss of $\mathrm{Ca}^{2+}$ signals (Supplementary Fig. S1; Supplementary Data are available online at www .liebertpub.com/scd). Therefore, the concentration-dependent elevation of $\left[\mathrm{Ca}^{2+}\right]_{i}$ was determined for the doses ranging between 1 and $100 \mu \mathrm{M}$. The amplitude of the glutamateinduced $\left[\mathrm{Ca}^{2+}\right]_{\mathrm{i}}$ responses at various concentrations ranged, respectively at $1 \mu \mathrm{M}=0.27 \pm 0.04, n=6$; at $10 \mu \mathrm{M}=0.29 \pm 0.04$, $n=6$; at $50 \mu \mathrm{M}=0.56 \pm 0.15, n=29$; and at $100 \mu \mathrm{M}=0.95 \pm 0.06$, $n=31$ (Fig. 4A, B). When the cells were exposed briefly, $10 \mathrm{~s}$, 

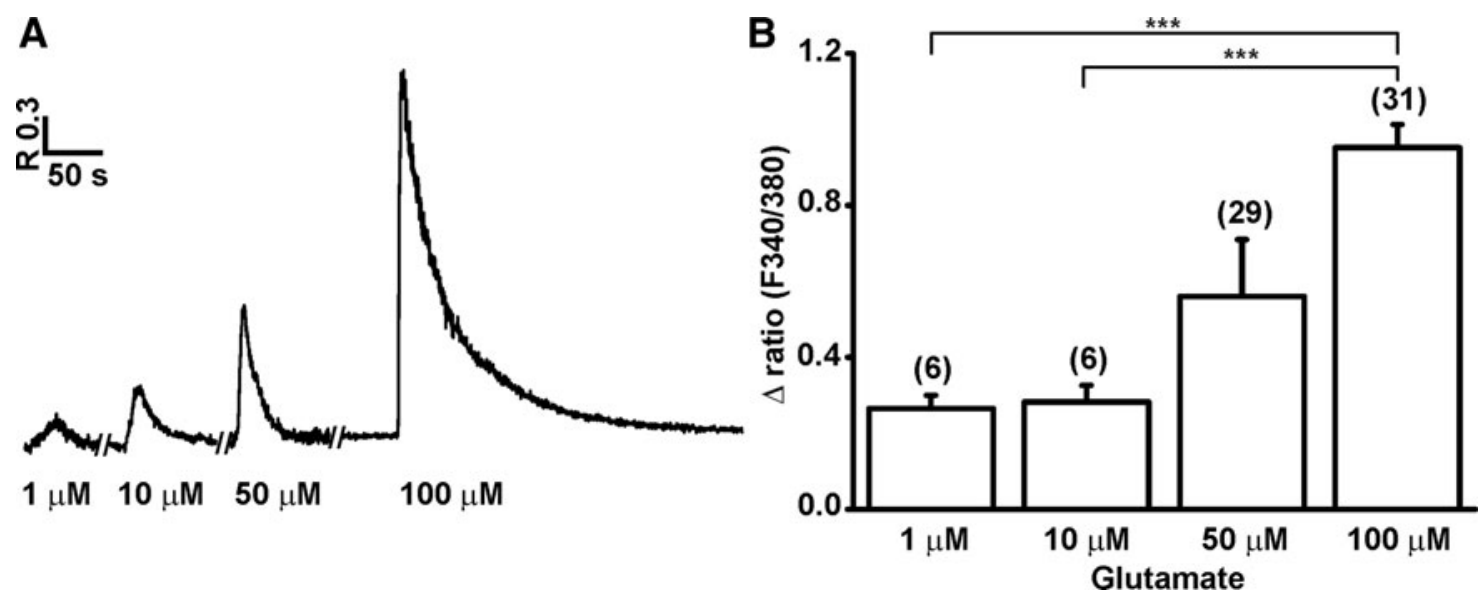

FIG. 4. Effect of glutamate in P7 hESC NPs. A representative trace (A) showing the $\left[\mathrm{Ca}^{2+}\right]_{\mathrm{i}}$ responses after the application of different concentrations of glutamate $(1-100 \mu \mathrm{M})$. A bar diagram (B) showing the amplitude $($ mean $\pm S E M)$ of the $\left[C a^{2+}\right]_{i}$ responses to the application of increased concentrations of glutamate. The number of cells tested is given in the parentheses. $* * * P=0.0005$.

to $1 \mathrm{mM}$ glutamate, there was a robust increase in $\left[\mathrm{Ca}^{2+}\right]_{\mathrm{i}}$, the $\mathrm{Ca}^{2+}$ level was high, sustained without any decay, and did not return to resting level even after wash of glutamate for a longer duration (Supplementary Fig. S1.) This phenomenon was observed in all 8 cells tested. Glutamatergic signals in the nervous system are mediated by ionotropic [NMDA, $\alpha$-amino-3-hydroxy-5-methyl-4-isoxazolepropionic acid (AMPA), and kainate] and metabotropic (mGlu) receptors. Two out of 9 tested cells were sensitive to the application of NMDA $(100 \mu \mathrm{M})$, while only 1 out of 6 cells was sensitive to kainic acid $(100 \mu \mathrm{M})$. To determine the contribution of metabotropic glutamate receptors, we applied glutamate in the absence of extracellular $\mathrm{Ca}^{2+}$; this caused a $\left[\mathrm{Ca}^{2+}\right]_{\mathrm{i}}$ increase in only 1 out of 9 cells suggesting that the sensitivity of P7 NPs to glutamate is mediated mainly by ionotropic glutamate receptors.

\section{Expression of neural markers in NPs derived from hESC}

The expression of various neural markers was analyzed in passages 6-10 (P6-P10) NPs. Table 1 shows the list of primary and secondary antibodies used. All immunocytochemical results were obtained from 2 independent stainings with each antibody. The results from P6-P10 are summarized in Table 3. The expression of various neural markers in P7 NPs is shown in Fig. 5. The neuronal markers NeuN (Fig. $5 \mathrm{Ba}$ ) and $\beta \mathrm{III}$ tubulin (Fig. $5 \mathrm{Ca}, \mathrm{Da}, \mathrm{Ea}, \mathrm{Fa}$ ) were expressed in all passages, with the highest expression in P6-P8. Immunostaining for neuronal marker MAP-2 was negative in all passages. Staining for nestin (Fig. $5 \mathrm{Aa}$ ), a marker of neural progenitor cells, revealed the presence of numerous nestin-positive cells in all passages of hESC. Glial cells markers such as glial fibrillary acidic protein (GFAP) (Fig. 5 $\mathrm{Db}, \mathrm{Gb}$ ) and astrocytic marker S100 (Fig. $5 \mathrm{Ab}, \mathrm{Bb}, \mathrm{Cb}, \mathrm{Hb}$ ) were also expressed throughout all passages except GFAP in P10. However, another astrocytic marker glutamine synthetase (Fig. $5 \mathrm{~Gb}$ ) and oligodendrocyte marker OLIG (Fig. 5 Fb) were detected only in P7 NPs. P7 NPs also expressed microglial marker Iba1 (Fig. 5 Eb). In contrast, P10 NPs, but not other passages showed positive immunostaining with anti-
NG2 chondroitin sulphate proteoglycan. Immunostaining with anti-glutamate was positive in P6 NPs, intensely positive in P7 NPs (Fig. $5 \mathrm{Ha}$ ), and absent in passages 8-10 (Table 3). The low expression of GABA was observed only in P6 and P8 NPs.

\section{Discussion}

\section{Remodeling of the $\left[\mathrm{Ca}^{2+}\right]_{i}$ signaling toolkit in hESC NPS}

Here, we demonstrated the functional remodeling of hESC NPs during propagation in vitro. While undifferentiated hESC were partially responsive only to ATP, predifferentiated cells expressed more sophisticated $\mathrm{Ca}^{2+}$ signaling mechanisms, characteristic of a neural phenotype. P7 and P8 hESC NPs express functional $\mathrm{Ca}^{2+}$ channels, ATP receptors, glutamate receptors, RyRs, and also demonstrate spontaneous $\mathrm{Ca}^{2+}$ oscillations. We found that the highest activity of $\mathrm{Ca}^{2+}$ signaling systems was observed at P7 and P8. This reflected data obtained in vivo, which showed that P8 NPs yielded the best results in terms of functional improvement after transplantation [19]. Thus, we may suggest that the behavior and fate of P7 and P8 hESC NPs after transplantation in vivo correlate with their elevated functional state as revealed by $\mathrm{Ca}^{2+}$ signaling. This rapid and transient remodeling of the $\mathrm{Ca}^{2+}$ the signaling toolkit represents, in our view, the most important finding of the present study. This shows that physiologically, hESCs cells may acquire a neuron-specific pattern of $\mathrm{Ca}^{2+}$ signaling but only for a short period limited to only 2 passages (Fig. 6). We have also determined the expression of a number of neuronal markers in undifferentiated and various passages of differentiated hESCs (Fig. 7; see also [19]) with the differential expression of various markers in hESC-NPs. We may further contemplate that the evaluation of $\mathrm{Ca}^{2+}$ signals in stem cells can be used to predict the fate of the cells during differentiation and can serve as an important criterion for assessing the quality of stem cells before their use in cell replacement therapy.

NPs derived from the CCTL14 line of hESCs at various passages show differences in their expression of genes and 

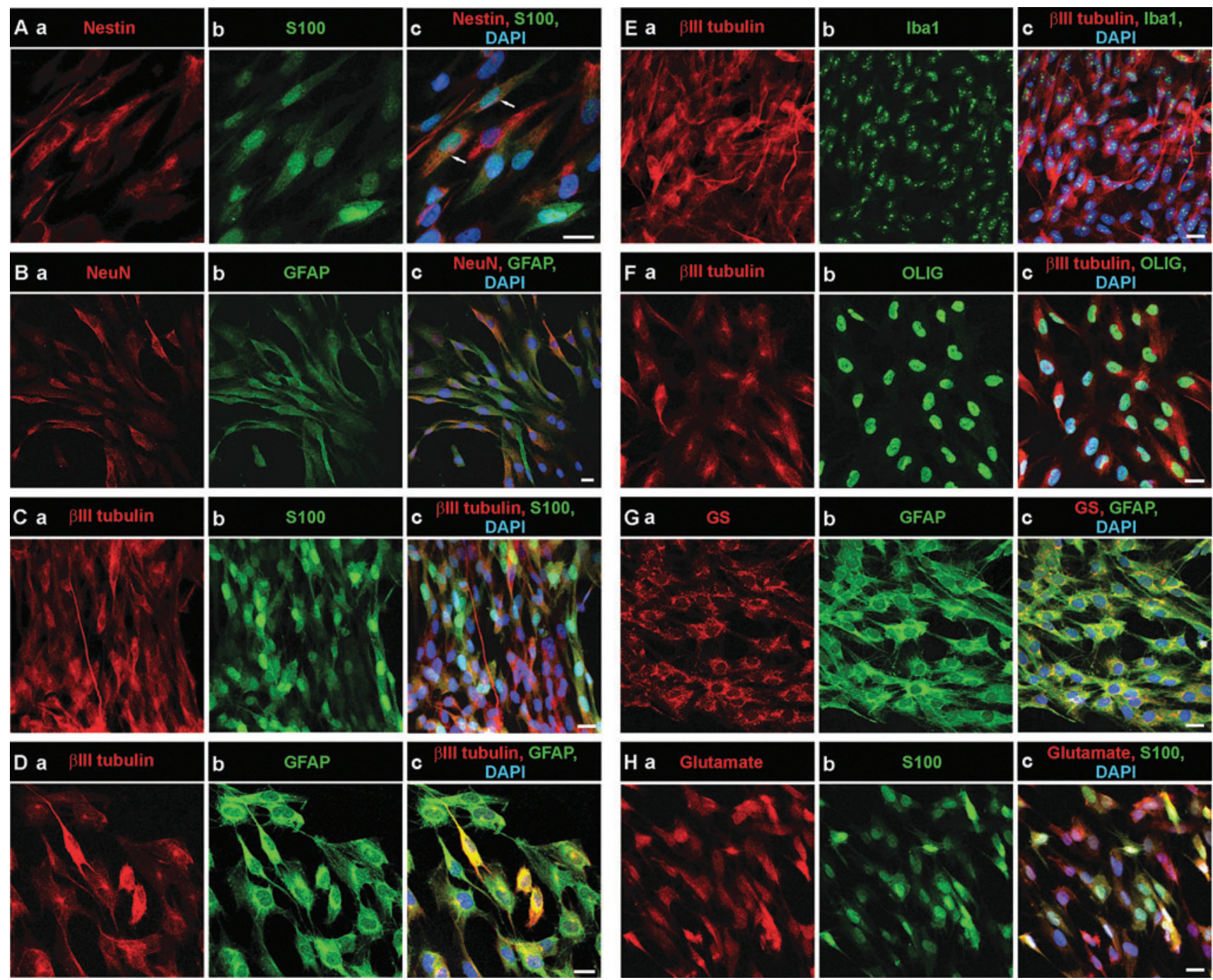

FIG. 5. Confocal microscopy analysis of the expression of neural cell markers in P7 NPs. P7 NPs express a number of neuronand glia-specific markers. (A) The proliferative marker nestin (Aa) is expressed in a majority of P7 NPs and in some cells (indicated by arrows) is co-localized (Ac) with the glial marker S100 (Ab, Ac). (B) P7 NPs express neuronal markers: NeuN, a marker of postmitotic neurons (Ba) and $\beta I I I$ tubulin (Ca, Da, Ea, Fa). The glial markers S100 (Ab, Cb, Hb), glial fibrillary acidic protein (GFAP) (Bb, Db, Gb), and glutamine synthetase $(\mathbf{G a})$, the oligodendrocyte marker OLIG (Fb) and the microglial marker Iba1 (Eb) are also expressed in P7 NPs. The majority of cells from P7 NPs show positive staining for glutamate (Ha). Nuclei were labeled with DAPI. Scale bars $=20 \mu \mathrm{m}$. Color images available online at www.liebertpub.com/scd

cell markers, and differences in the behavior of the cells after transplantation into the brain following middle cerebral artery occlusion in rats [19]. Therefore, our main attention was focused on studying the functional properties of NPs at different passages during maintenance in vitro that would be appropriate for transplantation.

Our results obtained from $\left[\mathrm{Ca}^{2+}\right]_{\mathrm{i}}$ measurements in single cells indicated that P6 NPs were sensitive mostly to glutamate $(27 \%)$, while only a small number of P6 NPs responded by an increase in $\left[\mathrm{Ca}^{2+}\right]_{\mathrm{i}}$ to other agonists, such as $50 \mathrm{mM} \mathrm{K}$ (11\%), ATP (7\%), GABA (7\%), or caffeine $(4 \%)$, suggesting an insignificant role for VOCCs and the absence of ATP-, GABA-, and RyR-generated $\mathrm{Ca}^{2+}$ signals in P6 NPs. Likewise, only a small population of P9 NPs was sensitive to $\mathrm{K}^{+}$ $(4 \%)$, ATP $(9 \%)$, or caffeine $(4 \%)$. The number of cells sensitive to glutamate significantly decreased to $9 \%$ in P9 NPs when compared with P6 NPs (27\%), and GABA was without any effect on $\left[\mathrm{Ca}^{2+}\right]_{\mathrm{i}}$. Unlike all other passages, P10 NPs were not sensitive to any of the applied stimuli (ATP, 5\%; $\mathrm{K}^{+}, 2 \%$; caffeine, $2 \%$; or GABA, $0 \%$ ). These results suggest that P10 NPs are generally devoid of $\mathrm{Ca}^{2+}$ signaling machinery. The highest number of cells responsive to at least one of the applied stimuli was found in NPs from passages 7 and 8 (59\% and 49\%, respectively). P7 NPs contained a significantly higher number of cells sensitive to glutamate $(57 \%$ in P7 NPs vs. $9 \%$ in P8 NPs), $\mathrm{K}^{+}(50 \%$ in P7 NPs vs. $32 \%$ in P8 NPs), and ATP (46\% in P7 NPs vs. $24 \%$ in P8 NPs). Almost equal populations of P7 NPs and P8 NPs were sensitive to caffeine (18\% and $16 \%$, respectively). The sensitivity to GABA increased to $16 \%$ in P8 NPs in comparison with P6 NPs (7\%); however, it should be noted that P9 NPs and P10 NPs were totally insensitive to GABA. These findings are in agreement with immunocytochemical results showing the expression of glutamate only in passages 6 and 7, faint 


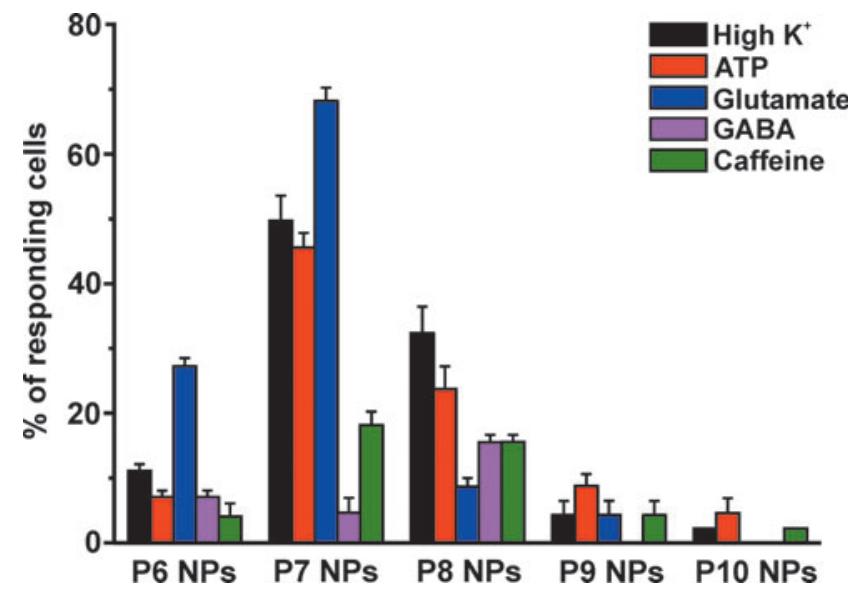

FIG. 6. The number of cells responding to various physiological stimuli in different passages of hESC-derived neural precursors [passage 6-10 (P6-P10 NPs)]. The number of cells from different passages of hESC NPs responding to various physiological stimuli [eg, $50 \mathrm{mM} \mathrm{K}^{+} ; 100 \mu \mathrm{M}$ ATP, $50 \mu \mathrm{M}$ glutamate; $10 \mu \mathrm{M} \gamma$-aminobutyric acid (GABA); $20 \mathrm{mM}$ caffeine] by a rise in $\left[\mathrm{Ca}^{2+}\right]_{i}$. Cells responding to 1 or more of the applied stimuli were considered as physiologically active. Color images available online at www.liebertpub.com/scd

expression of GABA in passages 8 and 6, but not in other passages (Table 3 ). The reasons for such peculiar signaling patterns remain unclear. Interestingly, the number of cells sensitive to various stimuli was consistently the highest in P7 NPs when compared with the other passages (Table 2, Fig. 6). Therefore, P7 NPs were chosen for the further detailed characterization of $\mathrm{Ca}^{2+}$ signaling mechanisms.

\section{Expression of VOCC in P7 hESC NPs}

$\mathrm{Ca}^{2+}$ entering the cytosol via VOCC regulates enzyme activity, gene expression, and other biochemical processes in cells. In neurons, VOCC also initiate synaptic transmission [37]. While L- and T-type currents are found in a wide range

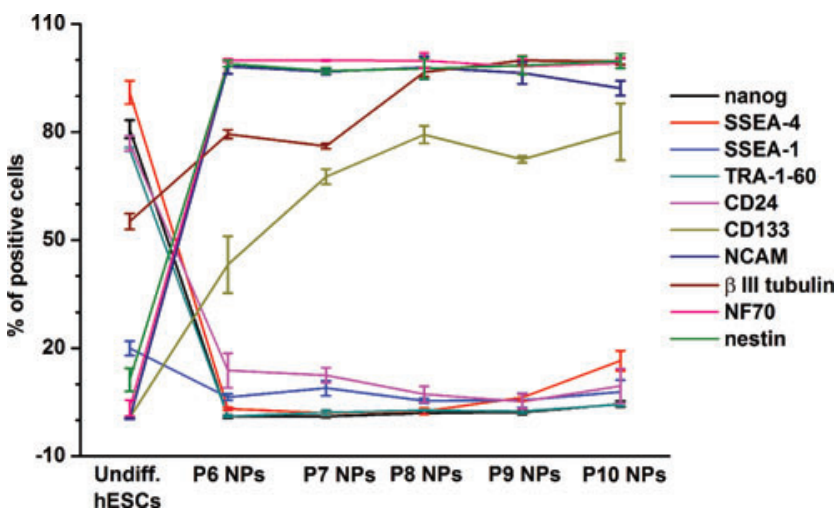

FIG. 7. Fluorescence-activated cell sorting profiles of pluripotent and neural markers in undifferentiated hESCs and hESC-derived NPs (P6-P10) during long-term propagation in vitro. Predifferentiation of hESC led to the downregulation of pluripotent markers (nanog, SSEA-4, SSEA-1, TRA-1-60, and CD24) and upregulation of neural markers (CD133, NCAM, $\beta$ III tubulin, NF70, and nestin). Color images available online at www.liebertpub.com/scd of cells, $\mathrm{N}-, \mathrm{P}, \mathrm{Q}-$, and R-type $\mathrm{Ca}^{2+}$ currents are most prominent in neurones. Depending on their localization in the cell, VOCC carry out different functions. For example, L-type VOCC located in the cell bodies and proximal dendrites induce gene activation, while $\mathrm{N}$ - and P/Q-type VOCC trigger the release of neurotransmitters at synaptic endings [9].

Previous studies have demonstrated the strong enhancement of neurogenesis by $\mathrm{Ca}^{2+}$ influx through L-type VOCC [38,39]. In neuronal cells derived from ESCs, Yu et al. [40] showed that cooperation between L-type VOCC and RyR2 is crucial for the activity-dependent neurogenesis induced by GABA signaling. In neural progenitors derived from hESCs after 30 days in culture, Malmersjo et al. observed an increase in $\left[\mathrm{Ca}^{2+}\right]_{\mathrm{i}}$ evoked by $50 \mathrm{mM} \mathrm{K}{ }^{+}$, but they did not specify which type of VOCC was activated [22]. Using reverse transcript (RT)-polymerase chain reaction (PCR) studies, others have shown the upregulation of VOCC expression in differentiated hESCs [23]. L-type channels are also expressed in NPs derived from human [25] and mouse ESCs [24].

Here, we identified the functional expression of L- and P/ Q-type VOCC in P7 NPs. Our findings are in accordance with the reports mentioned above; however, to the best of our knowledge, our study is the first to document the functional expression of $\mathrm{P} / \mathrm{Q} \mathrm{Ca}^{2+}$ channels in NPs derived from hESCs. Another interesting observation in this study was the lack of an effect of GVIA on $\mathrm{K}^{+}$-induced $\left[\mathrm{Ca}^{2+}\right]_{\mathrm{i}}$ responses and the absence of immunocytochemical staining for the $\alpha 1 \mathrm{~B}$ subunit of the N-type of $\mathrm{Ca}^{2+}$ channels.

Our data show that $\mathrm{P} / \mathrm{Q}$-type channels were functional in $50 \%$ of the cells tested (responsive to $50 \mathrm{mM} \mathrm{K}^{+}$) from P7 NPs. The application of $300 \mathrm{nM}$ up to $2 \mu \mathrm{M}$ MVIIC was reported to block several $\mathrm{P} / \mathrm{Q}$ - and $\mathrm{N}$-type $\mathrm{Ca}^{2+}$ channelregulated physiological functions [36,41,42]. In our case, high $\mathrm{K}^{+}$induced a $\left[\mathrm{Ca}^{2+}\right]_{\mathrm{i}}$ increase that was blocked by $1 \mu \mathrm{M}$ MVIIC in all tested cells, although the application of GVIA (500 and $800 \mathrm{nM}$ ), a selective N-type VOCC blocker, was not effective in blocking the $\mathrm{K}^{+}$-induced $\left[\mathrm{Ca}^{2+}\right]_{\mathrm{i}}$. This could be explained by the presence of $\mathrm{P} / \mathrm{Q}$ channels, which are sensitive to MVIIC but not to GVIA [30,36,43]. Indeed, the application of MVIIC at a $300 \mathrm{nM}$ concentration, effective in blocking the P/Q-type of VOCC, reduced the $\mathrm{Ca}^{2+}$ increase in all tested cells. In addition, immunocytochemical staining for the $\alpha 1 \mathrm{~B}$ subunit of the N-type of VOCC was negative, while immunostaining for the $\alpha 1 \mathrm{~A}$ subunit of the $\mathrm{P} / \mathrm{Q}$-type of VOCC was positive. Therefore, we conclude that P7 NPs express functional P/Q-, but not N-type, $\mathrm{Ca}^{2+}$ channels. An interesting finding was that there was no correlation between the immunocytochemical expression of VOCC and their functional activity. L- and P/Q-types of VOCC could be identified immunocytochemically in all passages without any significant differences, while functionally only P7 and P8 showed the expression of VOCC, while in other passages (P6, P9, and P10) VOCC were inactive.

It was previously shown that mouse ESC-derived neurones in the early stages of differentiation possess a complex pattern of VOCC, with a shift in channel contribution from $\mathrm{N}$ - and L-types in apolar cells to P/Q- and R-type channels in bi- and multipolar cells [21]. In our study, the $\left[\mathrm{Ca}^{2+}\right]_{i}$ increase in response to depolarization by $\mathrm{K}^{+}$was partially reduced by nicardipine, suggesting a possible role for L-type VOCC. 


\section{Purinergic receptor activation in P7 hESC NPS}

Purinergic receptors are widely distributed in the body and participate in the regulation of virtually all physiological processes. ATP acts as a fast excitatory neurotransmitter and has a potent long-term role in cell proliferation, growth, and development and also in disease and cytotoxicity $[44,45]$. Nervous system development, including progenitor cell proliferation, cell migration, neuronal and glial interactions, and differentiation and synaptic network formation are also controlled by purines $[13,46]$.

In our study, we used a series of agonists and antagonists to determine which subtypes of purinergic receptors are functional in P7 NPs. Suramin is generally selective as an antagonist for P2 receptors versus other types of receptors, but it does not discriminate between $\mathrm{P} 2 \mathrm{X}$ and $\mathrm{P} 2 \mathrm{Y}$ receptors [47]. In the present study, suramin reversibly inhibited the ATP-induced $\left[\mathrm{Ca}^{2+}\right]_{\mathrm{i}}$ increase by $65 \%$ in all tested cells, suggesting that P2 receptors are functional in P7 NPs. To discriminate between different types of P2X receptors, the selective $\mathrm{P} 2 \mathrm{X}_{1,3,5,7}$ agonist $\alpha, \beta$-me ATP was used; it displayed a similar high potency as ATP, which is typical for $\mathrm{P}_{2} \mathrm{X}_{1}$ and $\mathrm{P}_{2} \mathrm{X}_{3}$ receptors. The $\mathrm{P} 2 \mathrm{X}_{1,2,3,5}$ selective antagonist PPADS effectively blocked the ATP-induced $\left[\mathrm{Ca}^{2+}\right]_{i}$ increase by $75 \%$ in all tested cells. Another antagonist NF279, was not effective in low concentrations $(<100 \mu \mathrm{M})$, suggesting the absence of functional $\mathrm{P}_{2} \mathrm{X}_{1}$ and $\mathrm{P} 2 \mathrm{X}_{2}$ receptors. BzATP was effective in $18 \%$ of the cells tested. These data suggest the presence of functionally active $\mathrm{P} 2 \mathrm{X}_{3}$ and $\mathrm{P} 2 \mathrm{X}_{7}$ receptors, which were also confirmed by immunocytochemistry. While we were unable to characterize the function of $\mathrm{P}_{2} \mathrm{X}_{2}$ receptors pharmacologically, immunocytochemical staining showed the presence of $\mathrm{P}_{2} \mathrm{X}_{2}$ receptors in P7 NPs.

To the best of our knowledge there is only 1 study by Young et al. [23] that has demonstrated the presence of purinergic receptors in hESC-derived neural progenitors. Though the authors did not perform functional studies on P2 receptors, they showed by RT-PCR that in the hESC line WA09, the $\mathrm{P}_{2} \mathrm{X}_{4}$ subunits are upregulated in hNPs but downregulated in differentiated hNPs, while $\mathrm{P}_{2} \mathrm{X}_{7}$ was not expressed at any stage. In contrast, in our study CCTL14 hESC NPs expressed $\mathrm{P} 2 \mathrm{X}_{7}$, but not $\mathrm{P} 2 \mathrm{X}_{4}$ receptors. This might be explained by the difference in the cell lines used and by differences between the differentiation protocols themselves, since it is now well established that the effect of various neurotrophic factors such as GDNF, BDNF, NGF, and NT-3varies in dependence with a targeted cell type [48]. Others have shown that GABAergic neurones derived from mouse ESCs elevate $\left[\mathrm{Ca}^{2+}\right]_{i}$ predominantly via the activation of $\mathrm{P}_{2} \mathrm{X}_{2}, \mathrm{P}_{2} \mathrm{X}_{4}$, and $\mathrm{P} 2 \mathrm{Y}_{1}$ receptors [49]. In our study, we observed a $\left[\mathrm{Ca}^{2+}\right]_{i}$ increase in response to ATP also in the absence of extracellular $\mathrm{Ca}^{2+}$, suggesting the involvement of metabotropic P2Y receptors in the functioning of P7 NPs. We hypothesize that the functional properties of NPs are highly dependent on the origin of the cells and the differentiation conditions they are exposed to.

\section{$\mathrm{Ca}^{2+}$ stores in $\mathrm{P} 7 \mathrm{hESC}$ NPs}

In the nervous system $\mathrm{Ca}^{2+}$ release from internal stores plays an important role in regulating synaptic plasticity, neurite outgrowth, neurodegeneration, and secretion [50-52] and is also essential for triggering $\mathrm{Ca}^{2+}$ waves and oscillations in astrocytes [53]. It is regulated by 2 types of receptors, InsP $\mathrm{P}_{3} \mathrm{Rs}$ and RyRs, which are localized on the endoplasmic reticulum and in mitochondria [54,55]. Millimolar concentrations $(5-20 \mathrm{mM})$ of caffeine modulate intracellular $\mathrm{Ca}^{2+}$ signaling through the activation of RyR and at the same time the inhibition of $\mathrm{InsP}_{3} \mathrm{R}$ [56]. Therefore, depending on the relative densities of $\mathrm{RyR}$ and $\operatorname{Ins}_{3} \mathrm{R}$ in a particular cell, caffeine can either stimulate or block $\mathrm{Ca}^{2+}$ release from intracellular stores [57]. The release of $\mathrm{Ca}^{2+}$ from intracellular stores is well documented in ESC-derived cardiomyocytes $[58,59]$. In hESC-derived dopamine neurones, it was shown that dihydroxyphenylglycine-induced $\left[\mathrm{Ca}^{2+}\right]_{\mathrm{i}}$ increase was observed in the absence of extracellular $\mathrm{Ca}^{2+}$ suggesting the involvement of intracellular stores [22]. Other reports have shown that the RyR2 receptor, acting through $\mathrm{GABA}_{\mathrm{A}}$ receptors and L-type $\mathrm{Ca}^{2+}$ channels, induces neurogenesis in ESCs [40]. In our experiments, the application of caffeine caused an increase in $\left[\mathrm{Ca}^{2+}\right]_{\mathrm{i}}$, suggesting the activation of RyR; these findings were further confirmed by positive immunostaining for the RyR1 and RyR3 receptor. The application of CPA in P7 NPs resulted in a slow, long-lasting $\left[\mathrm{Ca}^{2+}\right]_{i}$ increase. These data suggest that P7 NPs possess mature and functional endoplasmic reticulum $\mathrm{Ca}^{2+}$ stores.

\section{Spontaneous $\left[\mathrm{Ca}^{2+}\right]_{i}$ oscillations in P7 hESC NPs}

Another interesting phenomenon that we observed is that hESC-NPs exhibited spontaneous oscillations in $\left[\mathrm{Ca}^{2+}\right]_{\mathrm{i}}$. Spontaneous $\left[\mathrm{Ca}^{2+}\right]_{\mathrm{i}}$ activity is an essential feature of developing neurones $[15,35,60]$. The elevation of $\left[\mathrm{Ca}^{2+}\right]_{i}$ in developing neurones in the form of $\mathrm{Ca}^{2+}$ spikes or $\mathrm{Ca}^{2+}$ waves regulates neuronal differentiation, axonal outgrowth, the development of potassium currents, the expression of GABA, and so on. We observed spontaneous $\left[\mathrm{Ca}^{2+}\right]_{i}$ transients in $31 \%$ of tested cells from P7 NPs with a mean frequency of $3.2 \mathrm{~min}$. These spontaneous transients were completely abolished by either the removal of extracellular $\mathrm{Ca}^{2+}$, or partially by the presence of VOCC blockers (N-, L-, and $\mathrm{P} / \mathrm{Q}$-type). Of interest, Spitzer et al. identified a few types of spontaneous $\left[\mathrm{Ca}^{2+}\right]_{\mathrm{i}}$ transients in developing neurones, including $\mathrm{Ca}^{2+}$ spikes and $\mathrm{Ca}^{2+}$ waves $[60,61] . \mathrm{Ca}^{2+}$ spikes functionally have been found to regulate the development of potassium currents and the expression of GABA $[62,63]$, while $\mathrm{Ca}^{2+}$ waves regulate neurite outgrowth [64]. We would classify the spontaneous $\mathrm{Ca}^{2+}$ elevations, based on their characteristics, observed in P7 NPs as $\mathrm{Ca}^{2+}$ waves. These data clearly indicate that P7 hESC NPs function in a similar manner as early neuronal cells. Similarly, it was reported that post mitotic neurons from hESCs exhibit spontaneous $\left[\mathrm{Ca}^{2+}\right]_{\mathrm{i}}$ transients, similar to $\left[\mathrm{Ca}^{2+}\right]_{\mathrm{i}}$ waves, and are mediated by $\mathrm{Gd}^{3+} / \mathrm{La}^{3+}$. Blocking these transients led to a significant reduction in progenitor cell proliferation [25].

\section{Glutamate and GABA receptors in P7 hESC NPs}

Since glutamate and GABA are important neurotransmitters and play a role in neuronal development [65], we next tested whether P7 NPs are sensitive to these 2 substances. Only $5 \%$ of tested cells $(n=44)$ were sensitive to the application of GABA. According to some reports [66-68], the $\left[\mathrm{Ca}^{2+}\right]_{\mathrm{i}}$ increase induced by GABA causes neuronal 
depolarization mainly in cells undergoing neuronal differentiation and only in a fraction of precursor and progenitor cells; also, the number of responding cells decreases with time. In addition, there are some concerns about using $\left[\mathrm{Ca}^{2+}\right]_{\mathrm{i}}$ to monitor the depolarizing action of GABA. Glutamate regulates proliferation and neuronal differentiation and also acts as a positive regulator in neurogenesis [69]. Glutamate acts via ionotropic NMDA, AMPA, and kainate receptors in addition to metabotropic mGlu receptors. Due to such a diversity of pathways, glutamate plays various roles in neurogenesis starting from the early stages of development $[69,70]$. In our study, we observed a $\left[\mathrm{Ca}^{2+}\right]_{\mathrm{i}}$ increase even in response to low concentrations of glutamate in a majority of cells tested (68\%). Similar findings have been previously reported in a few studies, for example in NP cells derived from hESCs differentiated into dopaminergic neurones [22]. Young et al. described the presence of AMPAand kainate- and the absence of NMDA-mediated $\mathrm{Ca}^{2+}$ responses in hESC-derived neural progenitors [23]. In our study, only a few P7 NPs were sensitive to NMDA and kainic acid, $22 \%$ and $17 \%$ respectively. We did not make further attempts to test the responses to AMPA suggesting that glutamate responses were most likely not mediated by NMDA or kainate glutamate receptors. Other authors have reported that the application of $500 \mu \mathrm{M}$ glutamate caused a rise in $\left[\mathrm{Ca}^{2+}\right]_{\mathrm{i}}$ in 34 out of 68 tested human NP cells, while only 3 out of 68 cells were depolarized by $50 \mathrm{mM} \mathrm{K}^{+}$[71]. In contrast, our results show that NP cells are sensitive to the application of even low $(1 \mu \mathrm{M})$ concentrations of glutamate, and $50 \%$ of cells were depolarized by $50 \mathrm{mM} \mathrm{K}^{+}$. Glutamate, when applied at $1 \mathrm{mM}$ caused $\mathrm{Ca}^{2+}$ overload led and to cell death (Supplementary Fig. S1). In the absence of extracellular $\mathrm{Ca}^{2+}$, the application of glutamate had no effect, suggesting the absence of functional mGlu receptors. Additionally, we found positive immunorectivity for the NR2D subunit of NMDA receptors in P7 NPs (Supplementary Fig. S2). This subunit has been shown to play an important role in synaptic transmission in the early stages of brain development.

Further, immunocytochemical results revealed that P7 NPs consist of heterogeneous cell populations including neural progenitor cells (nestin-positive), which have the capacity for self-renewal, and more mature cells showing a neuronal or glial phenotype. This heterogeneity is also reflected in the variety of $\mathrm{Ca}^{2+}$ channels and receptors present in P7 NPs. Some overlap in expression of neuronal marker $\beta I I I$ tubulin and glial marker GFAP was observed in all immunostaining throughout all passages. Of interest, it was previously reported [72-74] that both neurons and glial cells at certain time points can co-express $\beta$ III tubulin and GFAP. Interestingly, there was no significant difference between the immunocytochemical expression of VOCC and RyRs among P6-10 NPs, although the number of cells sensitive to the agonists of these receptors varied from P6 to P10, with significantly higher activation in P7 and P8 NPs.

\section{Conclusions}

Remarkable progress has been made recently in differentiating ESCs and other pluripotent stem cells into a neuronal phenotype $[2-5,75,76]$. To date, various growth factors and morphogenes, and cell markers, necessary for neuronal dif- ferentiation and development have been identified [77]. Nevertheless, many questions remain unanswered, in particular concerning the physiological development and functional activity of transplantable NPs derived from ESCs. Here, we correlate the histochemical and morphological features of hESC NPs with their physiological properties. Our findings clearly indicate that the predifferentiation of ESCs leads to an activation of $\mathrm{Ca}^{2+}$ signaling cascades and enhances the functional activity of the cells. We also showed that the $\mathrm{Ca}^{2+}$ signaling mechanisms and the physiological properties of hESC-derived NPs change during maintenance in vitro (Fig. 6). The mechanisms and factors that underlie these processes need to be established. Studying the functional properties of stem cells in vitro may help to predict their behavior and the fate of their physiopathological status in vivo and may serve as criteria to evaluate the quality of such cells. The preliminary results of this work have appeared as abstracts $[78,79]$. We conclude that the criteria to establish the histochemical characteristics and to identify the markers of differentiating cells do not reflect their functional state in terms of their signaling mechanisms. The evaluation of homeostatic signaling mechanisms could be considered as a key element in determining the "quality of stem cells". Therefore, understanding the physiology of stem cells may allow us to better control their regenerative potential, which in turn may help to improve strategies for their use in transplantation and the treatment of neurodegenerative diseases.

\section{Acknowledgments}

G. Dayanithi is supported by the "Centre National de la Recherche Scientifique," France. This work was supported by the grants GACR P304/11/2373 and GACR P304/12/ G069 from the Grant Agency of the Czech Republic, the FP7 project AXREGEN (PITN-GA-2008-214003), and the FP7 project Edu-GLIA (PITN-GA-2009-237956) Initial Training Network. We thank Silvia Bernascone for her participation in preliminary experiments and Hana Voriskova, IEM ASCR, for help with the immunocytochemical staining. We thank Carl Zeiss, s.r.o. Prague, Czech Republic for support and consultation on imaging and fluorescence photometry systems. We are very grateful to James Dutt, IEM ASCR, for helpful discussions and critical reading of the article.

\section{Author Disclosure Statement}

The authors declare they have no conflicts of interest.

\section{References}

1. Thomson JA, J Itskovitz-Eldor, SS Shapiro, MA Waknitz, JJ Swiergiel, VS Marshall and JM Jones. (1998). Embryonic stem cell lines derived from human blastocysts. Science 282:1145-1147.

2. Zhang SC, M Wernig, ID Duncan, O Brustle and JA Thomson. (2001). In vitro differentiation of transplantable neural precursors from human embryonic stem cells. Nat Biotechnol 19:1129-1133.

3. Reubinoff BE, P Itsykson, T Turetsky, MF Pera, E Reinhartz, A Itzik and T Ben-Hur. (2001). Neural progenitors from human embryonic stem cells. Nat Biotechnol 19:1134-1140.

4. Schulz TC, SA Noggle, GM Palmarini, DA Weiler, IG Lyons, KA Pensa, AC Meedeniya, BP Davidson, NA Lambert and BG Condie. (2004). Differentiation of human embryonic stem 
cells to dopaminergic neurons in serum-free suspension culture. Stem Cells 22:1218-1238.

5. Li XJ, ZW Du, ED Zarnowska, M Pankratz, LO Hansen, RA Pearce and SC Zhang. (2005). Specification of motoneurons from human embryonic stem cells. Nat Biotechnol 23:215221.

6. De Smedt H, A Verkhratsky and S Muallem. (2011). Ca(2+) signaling mechanisms of cell survival and cell death: an introduction. Cell Calcium 50:207-210.

7. Dayanithi G, O Forostyak, Y Ueta, A Verkhratsky and EC Toescu. (2012). Segregation of calcium signalling mechanisms in magnocellular neurones and terminals. Cell Calcium 51:293-299.

8. Toescu EC and G Dayanithi. (2012). Neuroendocrine signalling: natural variations on a $\mathrm{Ca}(2+)$ theme. Cell Calcium 51:207-211.

9. Berridge MJ, P Lipp and MD Bootman. (2000). The versatility and universality of calcium signalling. Nat Rev Mol Cell Biol 1:11-21.

10. Carafoli E, L Santella, D Branca and M Brini. (2001). Generation, control, and processing of cellular calcium signals. Crit Rev Biochem Mol Biol 36:107-260.

11. Munaron L, S Antoniotti and D Lovisolo. (2004). Intracellular calcium signals and control of cell proliferation: how many mechanisms? J Cell Mol Med 8:161-168.

12. Orrenius S, B Zhivotovsky and P Nicotera. (2003). Regulation of cell death: the calcium-apoptosis link. Nat Rev Mol Cell Biol 4:552-565.

13. Majumder P, CA Trujillo, CG Lopes, RR Resende, $\mathrm{KN}$ Gomes, KK Yuahasi, LR Britto and H Ulrich. (2007). New insights into purinergic receptor signaling in neuronal differentiation, neuroprotection, and brain disorders. Purinergic Signal 3:317-331.

14. North RA and A Verkhratsky. (2006). Purinergic transmission in the central nervous system. Pflugers Arch 452:479485 .

15. Berridge MJ. (1998). Neuronal calcium signaling. Neuron 21:13-26.

16. Spitzer NC. (2006). Electrical activity in early neuronal development. Nature 444:707-712.

17. LoTurco JJ, DF Owens, MJ Heath, MB Davis and AR Kriegstein. (1995). GABA and glutamate depolarize cortical progenitor cells and inhibit DNA synthesis. Neuron 15:12871298.

18. Haydar TF, F Wang, ML Schwartz and P Rakic. (2000). Differential modulation of proliferation in the neocortical ventricular and subventricular zones. J Neurosci 20:5764-5774.

19. Kozubenko N, K Turnovcova, M Kapcalova, O Butenko, M Anderova, V Rusnakova, M Kubista, A Hampl, P Jendelova and E Sykova. (2010). Analysis of in vitro and in vivo characteristics of human embryonic stem cell-derived neural precursors. Cell Transplant 19:471-486.

20. Rowe EW, DM Jeftinija, K Jeftinija and S Jeftinija. (2005). Development of functional neurons from postnatal stem cells in vitro. Stem Cells 23:1044-1049.

21. Arnhold S, C Andressen, DN Angelov, R Vajna, SG Volsen, J Hescheler and K Addicks. (2000). Embryonic stem-cell derived neurones express a maturation dependent pattern of voltage-gated calcium channels and calcium-binding proteins. Int J Dev Neurosci 18:201-212.

22. Malmersjo S, I Liste, O Dyachok, A Tengholm, E Arenas and P Uhlen. (2010). Ca2 + and cAMP signaling in human embryonic stem cell-derived dopamine neurons. Stem Cells Dev 19:1355-1364.
23. Young A, DW Machacek, SK Dhara, PR Macleish, M Benveniste, MC Dodla, CD Sturkie and SL Stice. (2011). Ion channels and ionotropic receptors in human embryonic stem cell derived neural progenitors. Neuroscience 192:793-805.

24. Zhang L, BE Blackman, MD Schonemann, T ZogovicKapsalis, X Pan, M Tagliaferri, HA Harris, I Cohen, RA Pera, et al. (2010). Estrogen receptor beta-selective agonists stimulate calcium oscillations in human and mouse embryonic stem cell-derived neurons. PLoS One 5:e11791.

25. Weick JP, M Austin Johnson and SC Zhang. (2009). Developmental regulation of human embryonic stem cell-derived neurons by calcium entry via transient receptor potential channels. Stem Cells 27:2906-2916.

26. Komori $Y, M$ Tanaka, M Kuba, M Ishii, M Abe, N Kitamura, A Verkhratsky, I Shibuya and G Dayanithi. (2010). Ca(2+) homeostasis, $\mathrm{Ca}(2+)$ signalling and somatodendritic vasopressin release in adult rat supraoptic nucleus neurones. Cell Calcium 48:324-332.

27. Dayanithi G, H Widmer and P Richard. (1996). Vasopressininduced intracellular $\mathrm{Ca} 2+$ increase in isolated rat supraoptic cells. J Physiol 490 (Pt 3):713-727.

28. Viero C, I Mechaly, H Aptel, S Puech, J Valmier, F Bancel and G Dayanithi. (2006). Rapid inhibition of Ca2 + influx by neurosteroids in murine embryonic sensory neurones. Cell Calcium 40:383-391.

29. Dayanithi G, M Chen-Kuo-Chang, C Viero, C Hamel, A Muller and G Lenaers. (2010). Characterization of Ca2+ signalling in postnatal mouse retinal ganglion cells: involvement of OPA1 in Ca2 + clearance. Ophthalmic Genet 31:53-65.

30. Dayanithi G, N Sabatier and H Widmer. (2000). Intracellular calcium signalling in magnocellular neurones of the rat supraoptic nucleus: understanding the autoregulatory mechanisms. Exp Physiol 85 Spec No:75S-84S.

31. Viero C and G Dayanithi. (2008). Neurosteroids are excitatory in supraoptic neurons but inhibitory in the peripheral nervous system: it is all about oxytocin and progesterone receptors. Prog Brain Res 170:177-192.

32. Lambert RC, G Dayanithi, FC Moos and P Richard. (1994). A rise in the intracellular $\mathrm{Ca} 2+$ concentration of isolated rat supraoptic cells in response to oxytocin. J Physiol $478 \mathrm{(Pt}$ 2):275-287.

33. Jamen F, G Alonso, I Shibuya, H Widmer, CM Vacher, A Calas, J Bockaert, P Brabet and G Dayanithi. (2003). Impaired somatodendritic responses to pituitary adenylate cyclase-activating polypeptide (PACAP) of supraoptic neurones in PACAP type I-receptor deficient mice. J Neuroendocrinol 15:871-881.

34. Widmer H, M Ludwig, F Bancel, G Leng and G Dayanithi. (2003). Neurosteroid regulation of oxytocin and vasopressin release from the rat supraoptic nucleus. J Physiol 548:233244.

35. Dayanithi G, I Mechaly, C Viero, H Aptel, S Alphandery, S Puech, F Bancel and J Valmier. (2006). Intracellular Ca2+ regulation in rat motoneurons during development. Cell Calcium 39:237-246.

36. Sabatier N, P Richard and G Dayanithi. (1997). L-, N- and Tbut neither P- nor Q-type Ca2 + channels control vasopressininduced $\mathrm{Ca} 2+$ influx in magnocellular vasopressin neurones isolated from the rat supraoptic nucleus. J Physiol 503 (Pt 2):253-268.

37. Tsien RW, D Lipscombe, DV Madison, KR Bley and AP Fox. (1988). Multiple types of neuronal calcium channels and their selective modulation. Trends Neurosci 11:431-438. 
38. Deisseroth K, S Singla, H Toda, M Monje, TD Palmer and RC Malenka. (2004). Excitation-neurogenesis coupling in adult neural stem/progenitor cells. Neuron 42:535-552.

39. Webb SE, M Moreau, C Leclerc and AL Miller. (2005). Calcium transients and neural induction in vertebrates. Cell Calcium 37:375-385.

40. Yu HM, J Wen, R Wang, WH Shen, S Duan and HT Yang. (2008). Critical role of type 2 ryanodine receptor in mediating activity-dependent neurogenesis from embryonic stem cells. Cell Calcium 43:417-431.

41. Pouille F, P Cavelier, T Desplantez, H Beekenkamp, PJ Craig, RE Beattie, SG Volsen and JL Bossu. (2000). Dendrosomatic distribution of calcium-mediated electrogenesis in purkinje cells from rat cerebellar slice cultures. J Physiol 527 (Pt 2):265-282.

42. Khosravani H and GW Zamponi. (2006). Voltage-gated calcium channels and idiopathic generalized epilepsies. Physiol Rev 86:941-966.

43. Lemos JR, SI Ortiz-Miranda, AE Cuadra, C VelazquezMarrero, EE Custer, T Dad and G Dayanithi. (2012). Modulation/physiology of calcium channel sub-types in neurosecretory terminals. Cell Calcium 51:284-292.

44. Abbracchio MP, G Burnstock, A Verkhratsky and H Zimmermann. (2009). Purinergic signalling in the nervous system: an overview. Trends Neurosci 32:19-29.

45. Burnstock G and A Verkhratsky. (2010). Long-term (trophic) purinergic signalling: purinoceptors control cell proliferation, differentiation and death. Cell Death Dis 1:e9.

46. Zimmermann H. (2011). Purinergic signaling in neural development. Semin Cell Dev Biol 22:194-204.

47. Ralevic V and G Burnstock. (1998). Receptors for purines and pyrimidines. Pharmacol Rev 50:413-492.

48. Allodi I, MS Guzman-Lenis, J Hernandez, X Navarro and E Udina. (2011). In vitro comparison of motor and sensory neuron outgrowth in a 3D collagen matrix. J Neurosci Methods 198:53-61.

49. Khaira SK, CW Pouton and JM Haynes. (2009). P2X2, P2X4 and $\mathrm{P} 2 \mathrm{Y} 1$ receptors elevate intracellular $\mathrm{Ca} 2+$ in mouse embryonic stem cell-derived GABAergic neurons. $\mathrm{Br} \mathrm{J}$ Pharmacol 158:1922-1931.

50. Rose CR and A Konnerth. (2001). Stores not just for storage. intracellular calcium release and synaptic plasticity. Neuron 31:519-522.

51. Meldolesi J. (2001). Rapidly exchanging Ca2+ stores in neurons: molecular, structural and functional properties. Prog Neurobiol 65:309-338.

52. Rizzuto R. (2001). Intracellular $\mathrm{Ca}(2+)$ pools in neuronal signalling. Curr Opin Neurobiol 11:306-311.

53. Kettenmann H, UK Hanisch, M Noda and A Verkhratsky. (2011). Physiology of microglia. Physiol Rev 91:461-553.

54. Berridge MJ. (2002). The endoplasmic reticulum: a multifunctional signaling organelle. Cell Calcium 32:235-249.

55. Bootman MD, MJ Berridge and HL Roderick. (2002). Calcium signalling: more messengers, more channels, more complexity. Curr Biol 12:R563-R565.

56. Verkhratsky A. (2005). Physiology and pathophysiology of the calcium store in the endoplasmic reticulum of neurons. Physiol Rev 85:201-279.

57. Vyleta NP and SM Smith. (2008). Fast inhibition of glutamate-activated currents by caffeine. PLoS One 3:e3155.

58. Sedan O, K Dolnikov, N Zeevi-Levin, N Leibovich, M Amit, J Itskovitz-Eldor and O Binah. (2008). 1,4,5-Inositol trisphosphate-operated intracellular $\mathrm{Ca}(2+)$ stores and angiotensinII/endothelin-1 signaling pathway are functional in human embryonic stem cell-derived cardiomyocytes. Stem Cells 26:3130-3138.

59. Satin J, I Itzhaki, S Rapoport, EA Schroder, L Izu, G Arbel, R Beyar, CW Balke, J Schiller and L Gepstein. (2008). Calcium handling in human embryonic stem cell-derived cardiomyocytes. Stem Cells 26:1961-1972.

60. Spitzer NC, NJ Lautermilch, RD Smith and TM Gomez. (2000). Coding of neuronal differentiation by calcium transients. Bioessays 22:811-817.

61. Spitzer NC. (1994). Spontaneous Ca2+ spikes and waves in embryonic neurons: signaling systems for differentiation. Trends Neurosci 17:115-118.

62. Desarmenien MG and NC Spitzer. (1991). Role of calcium and protein kinase $\mathrm{C}$ in development of the delayed rectifier potassium current in Xenopus spinal neurons. Neuron 7:797-805.

63. Spitzer NC, RC Debaca, KA Allen and J Holliday. (1993). Calcium dependence of differentiation of GABA immunoreactivity in spinal neurons. J Comp Neurol 337:168-175.

64. Gu X, EC Olson and NC Spitzer. (1994). Spontaneous neuronal calcium spikes and waves during early differentiation. J Neurosci 14:6325-6335.

65. Ben-Ari Y, JL Gaiarsa, R Tyzio and R Khazipov. (2007). GABA: a pioneer transmitter that excites immature neurons and generates primitive oscillations. Physiol Rev 87:1215-1284.

66. Wang J, DB Reichling, A Kyrozis and AB MacDermott. (1994). Developmental loss of GABA- and glycine-induced depolarization and $\mathrm{Ca} 2+$ transients in embryonic rat dorsal horn neurons in culture. Eur J Neurosci 6:1275-1280.

67. Obrietan K and AN van den Pol. (1995). GABA neurotransmission in the hypothalamus: developmental reversal from Ca2 + elevating to depressing. J Neurosci 15:5065-5077.

68. Maric D, I Maric, X Wen, JM Fritschy, W Sieghart, JL Barker and R Serafini. (1999). GABAA receptor subunit composition and functional properties of $\mathrm{Cl}$ - channels with differential sensitivity to zolpidem in embryonic rat hippocampal cells. J Neurosci 19:4921-4937.

69. Schlett K. (2006). Glutamate as a modulator of embryonic and adult neurogenesis. Curr Top Med Chem 6:949-960.

70. Melchiorri D, I Cappuccio, C Ciceroni, P Spinsanti, P Mosillo, I Sarichelou, P Sale and F Nicoletti. (2007). Metabotropic glutamate receptors in stem/progenitor cells. Neuropharmacology 53:473-480.

71. Piper DR, T Mujtaba, MS Rao and MT Lucero. (2000). Immunocytochemical and physiological characterization of a population of cultured human neural precursors. J Neurophysiol 84:534-548.

72. Draberova E, L Del Valle, J Gordon, V Markova, B Smejkalova, L Bertrand, JP de Chadarevian, DP Agamanolis, A Legido, et al. (2008). Class III beta-tubulin is constitutively coexpressed with glial fibrillary acidic protein and nestin in midgestational human fetal astrocytes: implications for phenotypic identity. J Neuropathol Exp Neurol 67: 341-354.

73. Hol EM, RF Roelofs, E Moraal, MA Sonnemans, JA Sluijs, EA Proper, PN de Graan, DF Fischer and FW van Leeuwen. (2003). Neuronal expression of GFAP in patients with Alzheimer pathology and identification of novel GFAP splice forms. Mol Psychiatry 8:786-796.

74. Casper KB and KD McCarthy. (2006). GFAP-positive progenitor cells produce neurons and oligodendrocytes throughout the CNS. Mol Cell Neurosci 31:676-684.

75. Wernig M, JP Zhao, J Pruszak, E Hedlund, D Fu, F Soldner, V Broccoli, M Constantine-Paton, O Isacson and R Jaenisch. 
(2008). Neurons derived from reprogrammed fibroblasts functionally integrate into the fetal brain and improve symptoms of rats with Parkinson's disease. Proc Natl Acad Sci U S A 105:5856-5861.

76. Dimos JT, KT Rodolfa, KK Niakan, LM Weisenthal, H Mitsumoto, W Chung, GF Croft, G Saphier, R Leibel, et al. (2008). Induced pluripotent stem cells generated from patients with ALS can be differentiated into motor neurons. Science 321:1218-1221.

77. Yuan SH, J Martin, J Elia, J Flippin, RI Paramban, MP Hefferan, JG Vidal, Y Mu, RL Killian, et al. (2011). Cell-surface marker signatures for the isolation of neural stem cells, glia and neurons derived from human pluripotent stem cells. PLoS One 6:e17540.

78. Forostyak O, N Kozubenko, S Bernascone, E Sykova and G Dayanithi. (2010). Physiology of calcium signalling in human embryonic stem cell-derived neural precursors. 7th Federation of European Neuroscience Scocieties. Forum of European Neuroscience, FENS Abstract, 5: 041.8.
79. Forostyak O, N Romanyuk, E Sykova and G Dayanithi. (2011). Physiology of $\mathrm{Ca}^{2+}$ signalling in human embryonic stem cell-derived neural precursors. GLIA 59 Suppl:1 Pages:S119-S119.

Address correspondence to: Prof. Govindan Dayanithi Department of Molecular Neurophysiology Institute of Experimental Medicine Academy of Sciences of the Czech Republic

Videnska 1083

CZ-142 20 Prague 4

Czech Republic

E-mail: gdaya@univ-montp2.fr; gdaya@biomed.cas.cz

Received for publication November 6, 2012

Accepted after revision January 7, 2013

Prepublished on Liebert Instant Online January 7, 2013 